\title{
State-Specific Patterns of Cigarette Smoking, Smokeless Tobacco Use, and E-Cigarette Use Among Adults - United States, 2016
}

\author{
S. Sean Hu, MD, DrPH ${ }^{1}$; David M. Homa, PhD, MPH ${ }^{1}$; Teresa Wang, PhD, $\mathrm{MS}^{1}$; \\ Yessica Gomez, $\mathrm{MPH}^{1}$; Kimp Walton, $\mathrm{MPH}^{1}$; Hua Lu, $\mathrm{MS}^{2}$; Linda Neff, $\mathrm{PhD}^{1}$
}

\begin{abstract}
Accessible Version: www.cdc.gov/pcd/issues/2019/18_0362.htm
Suggested citation for this article: Hu SS, Homa DM, Wang T, Gomez Y, Walton K, Lu H, et al. State-Specific Patterns of Cigarette Smoking, Smokeless Tobacco Use, and E-Cigarette Use Among Adults - United States, 2016. Prev Chronic Dis 2019; 16:180362. DOI: https://doi.org/10.5888/pcd16.180362.
\end{abstract}

\section{PEER REVIEWED}

\section{Summary}

What is already known on this topic?

Cigarettes and smokeless tobacco are the most prevalent forms of tobacco used among adults. Furthermore, the use of emerging tobacco products such as e-cigarettes has increased among adults, particularly among current and former adult cigarette smokers.

\section{What is added by this report?}

In US states in 2016, as many as 1 in 4 adults were current cigarette smokers (West Virginia); 1 in 10 adults currently used smokeless tobacco products (Wyoming); and 1 in 15 adults currently used e-cigarettes (OKlahoma).

What are the implications for public health practice?

Continued implementation of proven population-based interventions can help reduce adult tobacco use across tobacco product types, particularly in states with the highest prevalence of use.

\section{Abstract}

\section{Introduction}

State-level monitoring of changes in tobacco product use can help inform tobacco control policy and practice. This study examined state-specific prevalence of cigarette, smokeless tobacco, and e-cigarette use among US adults.

\section{Methods}

Data came from the 2016 Behavioral Risk Factor Surveillance System (BRFSS), a state-based telephone survey of US adults aged 18 years or older $(\mathrm{N}=477,665)$. Prevalence estimates for current (every day or some days) cigarette smoking, smokeless tobacco use, and e-cigarette use were calculated for all 50 states and the District of Columbia (DC) and stratified by sex and race/ethnicity. Because the 2016 BRFSS measured e-cigarette use for the first time, estimates of ever e-cigarette use and concurrent use of cigarettes and e-cigarettes were also calculated. We assessed subgroup differences with $\chi^{2}$ tests.

\section{Results}

In 2016, prevalence of current cigarette smoking among US adults ranged from $8.8 \%$ (Utah) to $24.8 \%$ (West Virginia), while prevalence of current smokeless tobacco use ranged from $1.3 \%$ (DC) to 9.8\% (Wyoming). For e-cigarettes, ever use ranged from $16.2 \%$ (DC) to $28.4 \%$ (Arkansas), and current use ranged from $2.4 \%$ (DC) to $6.7 \%$ (Oklahoma). Across all states, current e-cigarette use was significantly higher among current cigarette smokers than among former or never cigarette smokers. States with the highest prevalence of cigarette smoking generally had a high prevalence of current e-cigarette use.

\section{Conclusion}

Prevalence of adult cigarette smoking, smokeless tobacco use, and e-cigarette use varies across states. These findings underscore the importance of comprehensive statewide tobacco control and use prevention efforts that address the diverse tobacco products used among adults.

\section{Introduction}

Tobacco product use is the leading cause of preventable disease and death in the United States. Cigarette smoking, in particular, harms nearly every organ in the body and is responsible for about 
480,000 US deaths annually (1). Despite progress in reducing cigarette smoking in the United States, the tobacco product landscape has diversified. In 2015, about 1 in 5 US adults currently used some form of tobacco product (2). Cigarettes and smokeless tobacco are the most prevalent forms of tobacco used among adults (2-4). Although the prevalence of adult cigarette smoking has declined in many states, there has been little change in the prevalence of current smokeless tobacco use among adults in most states, and in some states the use of these products has increased $(3,5)$. Furthermore, the use of emerging tobacco products such as e-cigarettes has increased among adults, particularly among current and former adult cigarette smokers $(6,7)$.

Many US adults are also using multiple tobacco products (2). Although different tobacco products can have varying levels of addictive potential and harmful substances, concurrent use of multiple tobacco products can increase exposure to harmful and carcinogenic chemicals $(1,8)$. The prevalence of adults who report concurrent use of cigarettes and smokeless tobacco varies across states, and national data indicate that nearly $60 \%$ of current adult e-cigarette users were also current cigarette smokers in 2015 $(2,3,9-11)$. Smokeless tobacco and e-cigarettes are marketed as alternatives to cigarette smoking $(6,12)$. During 2014-2016, of US smokers who made a quit attempt within the past year, $35.3 \%$ reported using e-cigarettes during their quit attempts (13). E-cigarettes may help nonpregnant adult smokers if used as a complete substitute for all cigarettes and other smoked tobacco products; however, e-cigarettes are not approved by the Food and Drug Administration as a quit-smoking aid, and the US Preventive Services Task Force concluded that evidence is insufficient to recommend e-cigarettes for smoking cessation in adults, including pregnant women $(6,13,14)$.

Although previous studies have examined the state-specific prevalence of adult cigarette and smokeless tobacco use and concurrent use of these products (3-5), only 1 study to date has assessed state prevalence of adult e-cigarette use by using data from the 2014-2015 Tobacco Use Supplement to the Current Population Survey (10). However, that study did not assess differences by sociodemographic characteristics such as sex and race/ethnicity. More recent estimates of state-specific e-cigarette use among adults, including by demographics and cigarette smoking status, have not been reported. Therefore, the objective of this study was to report state-specific estimates of cigarette smoking, smokeless tobacco use, and e-cigarette use, as well as concurrent cigarette smoking and e-cigarette use, among US adults by using the 2016 Behavioral Risk Factor Surveillance System (BRFSS).

\section{Methods}

\section{Data source}

The BRFSS survey is an annual state-based random-digit-dialed telephone (landline and cellular telephone) survey, which has tracked health conditions and risk behaviors throughout the US annually since 1984. With support from the Centers for Disease Control and Prevention (CDC), the BRFSS survey is conducted by all 50 state health departments as well as those in the District of Columbia (DC), Puerto Rico, Guam, and the US Virgin Islands. Every month, data on health-related risk behaviors, clinical preventive health practices, and access to and use of health-care services are collected from a randomly selected, representative sample of noninstitutionalized adults aged 18 years or older residing in the United States. During 2016, a total of 477,665 respondents from all 50 states and DC completed the survey; the median survey response rate for all states, territories, and DC was $47.0 \%$ (range, 30.7\%-65.0\%). Detailed information about the BRFSS survey design, methods, and questionnaire are available at www.cdc.gov/brfss.

\section{Measures}

Three tobacco product types were assessed in the 2016 BRFSS Core Section: cigarettes, smokeless tobacco products (including chewing tobacco, snuff, and snus), and e-cigarettes. Current cigarette smokers were persons who reported smoking at least 100 cigarettes in their lifetime and smoking every day or some days at the time of the survey. Former cigarette smokers were persons who reported smoking at least 100 cigarettes in their lifetime but smoking "not at all" at the time of the survey. Never cigarette smokers were persons who never smoked or who smoked less than 100 cigarettes in their lifetime. Current smokeless tobacco use was defined as using chewing tobacco, snuff, or snus every day or some days at the time of the survey. Current e-cigarette use was defined as using e-cigarettes or other electronic "vaping" products every day or some days at the time of survey. Ever e-cigarette use was defined as having ever using an e-cigarette or other electronic "vaping" product, even just 1 time, during the respondent's lifetime.

\section{Analysis}

Prevalence estimates with $95 \%$ confidence intervals were calculated for current cigarette smoking, current smokeless tobacco use, and current and ever e-cigarette use. Estimates were calculated overall, by state, and by sex. Data were additionally stratified by race/ethnicity for ever e-cigarette use. Because of the limited sample sizes, these stratifications were not performed for current cigarette smoking, smokeless tobacco use, or e-cigarette use.

\footnotetext{
The opinions expressed by authors contributing to this journal do not necessarily reflect the opinions of the U.S. Department of Health and Human Services, the Public Health Service, the Centers for Disease Control and Prevention, or the authors' affiliated institutions.
} 
Race/ethnicity groups were categorized as non-Hispanic white, non-Hispanic black, Hispanic, and non-Hispanic other (Asian, Native Hawaiian or other Pacific Islander, American Indian or Alaska Native, or some other group). The prevalence of current, former, and never cigarette smokers among current e-cigarette users was also assessed. Estimates for current cigarette smoking and current e-cigarette use were stratified into quartiles and mapped to illustrate the relative distribution of prevalence by state.

Data were weighted to yield state representative estimates while taking into account the probability of selection and adjusting for nonresponse bias and noncoverage errors. We used $\chi^{2}$ tests to assess differences among groups, with $P<.05$ considered to be significant. All analyses were conducted using SAS version 9.4 (SAS Institute, Inc) survey procedures to account for the complex survey sampling design.

\section{Results}

\section{Cigarettes}

Prevalence of current cigarette smoking ranged from $8.8 \%$ (Utah) to $24.8 \%$ (West Virginia) (Table 1). By sex, the prevalence of cigarette smoking was significantly higher among men than women in 40 states and DC. Estimates ranged from 10.4\% (Utah) to $25.8 \%$ (West Virginia) among men and from 7.1\% (Utah) to $24.0 \%$ (Kentucky) among women. Seven of the 10 states with the highest prevalence of current cigarette smoking were in the South (West Virginia [24.8], Kentucky [24.5], Arkansas [23.6], Louisiana [22.8], Mississippi [22.7], Tennessee [22.1], and Alabama [21.5]), while the remaining 3 states were in the Midwest (Ohio [22.5], Missouri [22.1], and Indiana [21.1]). In contrast, 8 of the 10 states with the lowest prevalence of current cigarette smoking were in the West (Utah [8.8], California [11.0], Hawaii [13.1], and Washington [13.9]) or Northeast (Connecticut [13.3], Massachusetts [13.6], New Jersey [14.0], and New York [14.2]); the remaining 2 states were in the South (Maryland [13.7] and Texas [14.3]).

\section{Smokeless tobacco}

Prevalence of current smokeless tobacco use ranged from 1.3\% (DC) to 9.8\% (Wyoming) (Table 1). Prevalence of current smokeless tobacco use was significantly higher among men than women in 41 states for which statistically stable estimates among women could be computed. Prevalence ranged from 1.8\% (DC) to $17.0 \%$ (Wyoming) among men and from $0.3 \%$ (California) to $2.3 \%$ (Wyoming) among women. Five of the 10 states with the highest prevalence of current smokeless tobacco use were in the South (West Virginia [8.5], Arkansas [7.8], Kentucky [7.4], Mississippi
[7.2], and Tennessee [6.8]), 4 states were in the West (Wyoming [9.8], Montana [7.7], Alaska [6.3], and Idaho [6.1]), and 1 state was in the Midwest (North Dakota [7.1]).

\section{E-cigarettes}

Prevalence of ever e-cigarette use ranged from $16.2 \%$ (DC) to $28.4 \%$ (Arkansas) (Table 2), and was significantly higher among men than women in 47 states and DC. Prevalence also differed significantly by race/ethnicity in 41 states and DC for which statistically stable estimates could be computed. The prevalence of ever use of e-cigarettes ranged from $20.5 \%$ (DC) to $30.4 \%$ (Alaska) among men and from $12.5 \%$ (DC) to $26.9 \%$ (Arkansas) among women. Prevalence of ever e-cigarette use ranged from $16.4 \%$ (DC) to $30.1 \%$ (Arkansas) among non-Hispanic whites, from $14.4 \%$ (Mississippi) to $38.5 \%$ (New Mexico) among nonHispanic blacks, from $12.4 \%$ (North Carolina) to $43.4 \%$ (Alaska) among Hispanics, and from 14.2\% (Maryland) to $42.7 \%$ (Mississippi) among non-Hispanics of other races.

Prevalence of current e-cigarette use ranged from $2.4 \%$ (DC) to $6.7 \%$ (Oklahoma) (Table 1). The prevalence of current e-cigarette use was significantly higher among men than among women in 30 of 50 states and DC. Prevalence ranged from 3.3\% (South Dakota) to $7.9 \%$ (Oklahoma) among men and $1.4 \%$ (DC) to $5.6 \%$ (Ohio) among women. Five of the 10 states with the highest prevalence of current e-cigarette smoking were in the South (Oklahoma [6.7], Louisiana [6.0], Arkansas [5.8], Tennessee [5.7], and Kentucky [5.6]); 3 states were in the West (Nevada [6.0], Wyoming [5.5], and Arizona [5.3]); and 2 states were in the Midwest (Ohio [5.7] and Wisconsin [5.3]).

\section{Cigarette smoking among current e-cigarette users}

Among current adult e-cigarette users, the prevalence of current cigarette smoking was significantly higher than the prevalence of former cigarette smoking or never cigarette smoking in all 50 states and DC (Table 3). Among current e-cigarette users, the prevalence of current cigarette smoking ranged from $36.7 \%$ (Utah) to $72.1 \%$ (Missouri); the prevalence of former cigarette smokers ranged from $19.3 \%$ (Missouri) to $44.8 \%$ (Alaska); and the prevalence of never cigarette smokers ranged from $7.1 \%$ (Maine) to $32.2 \%$ (California). More than half of current e-cigarette users were current cigarette smokers in 39 states, ranging from 50.6\% (Rhode Island) to $72.1 \%$ (Missouri).

Of the 12 states (Alabama, Arkansas, Indiana, Kentucky, Louisiana, Michigan, Mississippi, Missouri, Ohio, South Carolina, Tennessee, and West Virginia) that were in the highest quartile of current cigarette smoking prevalence (prevalences of $19.9 \%-24.8 \%$ ), 5 of these states (Arkansas, Kentucky, Louisiana, Ohio, and Tennessee) also were in the highest quartile of current e-cigarette use

The opinions expressed by authors contributing to this journal do not necessarily reflect the opinions of the U.S. Department of Health and Human Services, the Public Health Service, the Centers for Disease Control and Prevention, or the authors' affiliated institutions. 
(prevalences of 5.3\%-6.7\%). Four of the 12 states (Alabama, Michigan, Missouri, and South Carolina) were in the secondhighest quartile of current e-cigarette use (prevalences of $4.8 \%-5.2 \%$ ); and 3 of the 12 states (Indiana, Mississippi, and West Virginia) were in the third-highest quartile of current e-cigarette use (prevalences of $4.2 \%-4.7 \%$ ) (Figure).

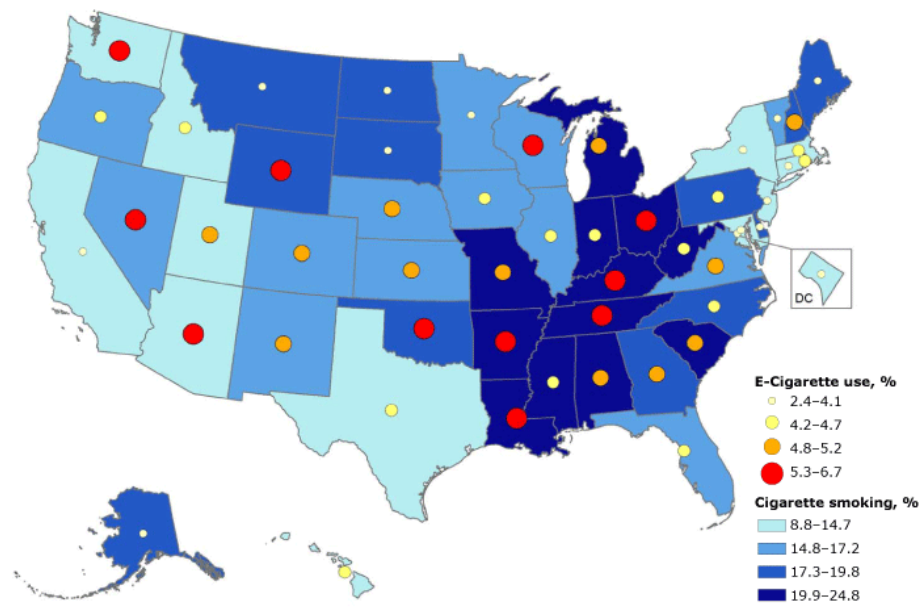

Figure. State-specific prevalence of current cigarette smoking and e-cigarette use among adults aged 18 years or older, by percentile - Behavioral Risk Factor Surveillance System, United States, 2016. Current cigarette smoking was defined as persons aged 18 years or older who reported having smoked 100 or more cigarettes during their lifetime and smoked every day or some days at the time of survey; it excludes respondents whose smoking status was unknown. E-cigarette use was defined as persons aged 18 years or older who reported currently using e-cigarettes every day or some days at the time of survey; it excludes respondents whose using status was unknown.

\section{Discussion}

Across US states in 2016, prevalence of current tobacco product use varied most for cigarettes, followed by smokeless tobacco and e-cigarettes. Three states (Arkansas, Kentucky, and Tennessee) were among the top 10 states with the highest prevalence for all 3 assessed tobacco product types. As many as 1 in 4 adults were current cigarette smokers (West Virginia); 1 in 10 adults used smokeless tobacco products (Wyoming); and 1 in 15 adults currently used e-cigarettes (Oklahoma). As the tobacco product landscape continues to diversify, these findings underscore the importance of sustained monitoring and reporting of adult tobacco use across tobacco product types to help inform comprehensive tobacco use prevention and control strategies.

There has been significant public health progress in the reduction of adult cigarette smoking in the United States (1). Compared with previous state level BRFSS estimates (5), our findings suggest the prevalence of current cigarette smoking among US adults declined significantly in all 50 states and DC except Tennessee from 2011 to 2016. Nevertheless, our study reinforces that cigarette smoking is still the most common form of tobacco product used among US adults. The 2016 National Health Interview Survey estimates that $15.5 \%$ percent of adults (37.8 million) are current smokers (15). Consistent with previous observations, however, our study also indicates that cigarette smoking prevalence is higher among adults living in certain US regions, including the Midwest and the South, than in the Northeast and West $(1,5,10)$. Thus, the statewide use of evidence-based tobacco control interventions, including tobacco product price increases, smoke-free policies, increased access to cessation services, and hard-hitting mass-media campaigns, are critical to further reduce cigarette smoking and smoking-related disease and death among US adults $(1,16)$.

In contrast to cigarette smoking patterns, smokeless tobacco use has not declined commensurately among US adults (1). For instance, the range of smokeless tobacco use prevalence presented in this report $(1.3 \%-9.8 \%)$ is consistent with the previously published range from 2011 (1.4\%-8.9\%) (5). Moreover, during 2011 through 2016, most states either experienced no significant change or an increase in the prevalence of smokeless tobacco use among adults. These trends align with the detected increase in smokeless tobacco consumption (17) and may be partly attributed to increased expenditures for advertising and promotion of these products, from \$684.9 million in 2015 to $\$ 759.3$ million in 2016 (18). Given that smokeless tobacco also causes substantial morbidity and premature mortality (1), these data demonstrate the public health importance of incorporating smokeless tobacco products within the framework of comprehensive tobacco use prevention and control programs.

We also presented the most recent state-specific prevalence estimates of current and ever e-cigarette use among US adults. Our findings indicate that across these jurisdictions, the prevalence of ever e-cigarette use was 3.7 (in Utah) to 7.0 (in South Dakota) times higher than the prevalence of current e-cigarette use. Although BRFSS included these indicators for the first time in 2016, the Tobacco Use Supplement to the Current Population survey assessed e-cigarette use during 2014-2015 (10). The measures used to define current and ever e-cigarette use were consistent between surveys. Variations between estimates derived from these 2 data sets may be due in part to differences in survey mode, sample size, and sampling time frame. Moreover, data from other nationally representative studies suggest that trends in ever and current e-cigarette use continue to evolve. For instance, Bao and colleagues examined data from the National Health Interview Survey between 2014 and 2016 and reported a significant increase in the prevalence of ever e-cigarette use among US adults (from $12.6 \%$ to

The opinions expressed by authors contributing to this journal do not necessarily reflect the opinions of the U.S. Department of Health and Human Services, the Public Health Service, the Centers for Disease Control and Prevention, or the authors' affiliated institutions. 
$15.3 \%)$ but a decline in the prevalence of current e-cigarette use (from $3.7 \%$ to $3.2 \%$ ) (19). These differences may be partly due to competing factors related to e-cigarette experimentation and discontinuation of their use (20).

A substantial proportion of adult tobacco users use more than 1 product (1). In 2016, current e-cigarette users were predominantly comprised of current cigarette smokers in most US states and DC. This held true even in states with low cigarette smoking prevalence. For example, although Utah had the lowest prevalence of current cigarette smoking $(8.8 \%)$, it also had the highest percentage of current e-cigarette use among its adult population of current cigarette smokers $(21.1 \%)$. That being said, the national prevalence of e-cigarette use has increased significantly among former and never smokers over time (19). The patterns and trajectories of tobacco product use among nonsmokers warrants further monitoring, including among adolescents, young adults, and adults more generally (21).

To our knowledge, this is the first study to assess state-specific prevalence of cigarette smoking, smokeless tobacco use, and e-cigarette use among adults in all 50 US states and DC by sex and race/ethnicity. Significant differences in state-specific tobacco product use were identified between these 2 subgroups. For instance, men had a higher prevalence of cigarette smoking than women. The use of smokeless tobacco was particularly high among men compared with women, with Wyoming having the highest prevalence of smokeless tobacco use among both men (17.0\%) and women $(2.3 \%)$. These differences might be partly explained by sociocultural influences, including advertising and promotion of these products, as well as varying social norms related to the acceptability of tobacco use $(22,23)$. Furthermore, studies have demonstrated that pregnant women and women of childbearing age may be prompted to switch from cigarettes to e-cigarettes or to engage in dual use of these products $(24,25)$. Although e-cigarettes may help nonpregnant adult smokers if used as a complete substitute for cigarettes or other combustible tobacco products, the long-term effectiveness of these products for smoking cessation is inconclusive, including for pregnant women (14). Furthermore, the prevalence of ever e-cigarette use among US adults varied widely by race/ethnicity across states. These differences are consistent with national estimates citing higher current e-cigarette use among non-Hispanic whites and non-Hispanics of other or multiple races (2). Significant differences in tobacco product use can exist by other sociodemographics characteristics, including age; for instance, the overall prevalence of current e-cigarette use is high among young adults $(6,11,19)$. Taken together, findings from this study highlight some of the key disparities associated with use of different tobacco products, which can be minimized by comprehensive state tobacco control programs that address the diverse tobacco products being used among US adults.

The findings in this report are subject to at least 3 limitations. First, BRFSS does not include adults without wireless or landline telephone service; however, their exclusion would not be expected to introduce any major bias because only $3.1 \%$ of US adults reported having no telephone service in 2016 (26). Second, these data are self-reported and might be subject to reporting bias. Although these self-reported tobacco use estimates were not biochemically validated, previous meta-studies identified overall high concordance between self-reported tobacco product use behaviors and biochemical assessment with cotinine (27). Finally, the median state response rates ranged from $25.1 \%$ to $60.1 \%$. Even after adjusting for nonresponse, low response rates can increase the potential for bias if there are systematic differences between respondents and nonrespondents; however, BRFSS has been shown to be valid and reliable (28).

The prevalence of adult cigarette smoking, smokeless tobacco use, and e-cigarette use varies across states. The findings have implications for interventions and programs addressing the diverse tobacco products used among US adults, including newer products such as e-cigarettes. Continued implementation of proven population-based interventions, including increasing tobacco product prices, implementing and enforcing comprehensive smoke-free laws, warning about the dangers of tobacco product use through mass media campaigns, and increasing barrier-free access to evidence-based cessation treatments such as behavioral counseling and Food and Drug Administration-approved medication, can help reduce tobacco use, particularly in states with the highest prevalence of use (16). Establishing these evidence-based strategies to encompass all tobacco products, including e-cigarettes, could minimize the potential adverse effects of e-cigarette use among vulnerable populations, including adolescents, while also maximizing any potential benefits among adult smokers who might use ecigarettes to quit smoking completely $(6,29)$.

\section{Acknowledgments}

No funding was secured for this study. The findings and conclusions in this manuscript are those of the authors and do not necessarily represent the official position of CDC. The authors thank Ahmed Jamal, CDC, for his guidance on this analysis. No copyrighted material, surveys, instruments, or tools were used in this study.

The opinions expressed by authors contributing to this journal do not necessarily reflect the opinions of the U.S. Department of Health and Human Services, the Public Health Service, the Centers for Disease Control and Prevention, or the authors' affiliated institutions. 


\section{Author Information}

Corresponding author: S. Sean Hu, MD, DrPH, Office on Smoking and Health, National Center for Chronic Disease Prevention and Health Promotion, Centers for Disease Control and Prevention, Mailstop S107-7, 4770 Buford Hwy NE, Atlanta, GA 30341. Telephone: 770-488-5845. Email: fik4@cdc.gov.

Author Affiliations: ${ }^{1}$ Office on Smoking and Health, National Center for Chronic Disease Prevention and Health Promotion, Centers for Disease Control and Prevention, Atlanta, Georgia. ${ }^{2}$ Division of Population Health, National Center for Chronic Disease Prevention and Health Promotion, Centers for Disease Control and Prevention, Atlanta, Georgia.

\section{References}

1. US Department of Health and Human Services. The health consequences of smoking - 50 years of progress: a report of the Surgeon General. Atlanta (GA): US Department of Health and Human Services, Centers for Disease Control and Prevention, National Center for Chronic Disease Prevention and Health Promotion, Office on Smoking and Health; 2014.

2. Phillips E, Wang TW, Husten CG, Corey CG, Apelberg BJ, Jamal A, et al. Tobacco product use among adults - United States, 2015. MMWR Morb Mortal Wkly Rep 2017; 66(44):1209-15.

3. Nguyen KH, Marshall L, Brown S, Neff L. State-specific prevalence of current cigarette smoking and smokeless tobacco use among adults - United States, 2014. MMWR Morb Mortal Wkly Rep 2016;65(39):1045-51.

4. Hu SS, Neff L, Agaku IT, Cox S, Day HR, Holder-Hayes E, et al. Tobacco product use among adults - United States, 2013-2014. MMWR Morb Mortal Wkly Rep 2016; 65(27):685-91.

5. Nguyen K, Marshall L, Hu S, Neff L; Centers for Disease Control and Prevention (CDC). State-specific prevalence of current cigarette smoking and smokeless tobacco use among adults aged $\geq 18$ years - United States, 2011-2013. MMWR Morb Mortal Wkly Rep 2015;64(19):532-6.

6. US Department of Health and Human Services. E-cigarette use among youth and young adults. A report of the Surgeon General. Atlanta (GA): US Department of Health and Human Services, Centers for Disease Control and Prevention, National Center for Chronic Disease Prevention and Health Promotion, Office on Smoking and Health; 2016.
7. Jamal A, Gentzke A, Hu SS, Cullen KA, Apelberg BJ, Homa $\mathrm{DM}$, et al. Tobacco use among middle and high school students - United States, 2011-2016. MMWR Morb Mortal Wkly Rep 2017;66(23):597-603.

8. Teo KK, Ounpuu S, Hawken S, Pandey MR, Valentin V, Hunt $\mathrm{D}$, et al. Tobacco use and risk of myocardial infarction in 52 countries in the INTERHEART study: a case-control study. Lancet 2006;368(9536):647-58.

9. Schoenborn CA, Gindi RM. Electronic cigarette use among adults: United States, 2014. NCHS Data Brief 2015;(217):1-8. https://www.cdc.gov/nchs/data/databriefs/db217.pdf. Accessed January 16, 2018.

10. Odani S, Armour BS, Graffunder CM, Willis G, Hartman AM, Agaku IT. State-specific prevalence of tobacco product use among adults - United States, 2014-2015. MMWR Morb Mortal Wkly Rep 2018;67(3):97-102.

11. QuickStats: cigarette smoking status* among current adult ecigarette users, $\uparrow$ by age group - National Health Interview Survey, § United States, 2015. MMWR Morb Mortal Wkly Rep 2016;65(42):1177.

12. Delnevo CD, Wackowski OA, Giovenco DP, Manderski MT, Hrywna M, Ling PM. Examining market trends in the United States smokeless tobacco use: 2005-2011. Tob Control 2014; 23(2):107-12.

13. Caraballo RS, Shafer PR, Patel D, Davis KC, McAfee TA. Quit methods used by US adult cigarette smokers, 2014-2016. Prev Chronic Dis 2017;14:E32.

14. National Academies of Sciences, Engineering, and Medicine. Public health consequences of e-cigarettes. Washington (DC): The National Academies Press; 2018.

15. Jamal A, Phillips E, Gentzke AS, Homa DM, Babb SD, King BA, et al. Current cigarette smoking among adults - United States, 2016. MMWR Morb Mortal Wkly Rep 2018; 67(2):53-9.

16. Centers for Disease Control and Prevention. Best practices user guide: health equity. Atlanta (GA): US Department of Health and Human Services, Centers for Disease Control and Prevention; 2015. http://www.cdc.gov/tobacco/ stateandcommunity/best-practices-health-equity/index.htm. Accessed June 28, 2018.

17. Wang TW, Kenemer B, Tynan MA, Singh T, King B. Consumption of combustible and smokeless tobacco - United States, 2000-2015. MMWR Morb Mortal Wkly Rep 2016; 65(48):1357-63.

\footnotetext{
The opinions expressed by authors contributing to this journal do not necessarily reflect the opinions of the U.S. Department of Health and Human Services, the Public Health Service, the Centers for Disease Control and Prevention, or the authors' affiliated institutions.
} 
18. Federal Trade Commission. Federal Trade Commission smokeless tobacco report for 2016. Washington (DC): Federal Trade Commission, 2018. https:/www.ftc.gov/system/files/ documents/reports/federal-trade-commission-cigarette-report2016-federal-trade-commission-smokeless-tobacco-report/ftc smokeless_tobacco_report_for_2016_0.pdf. Accessed June 26, 2018.

19. Bao W, Xu G, Lu J, Snetselaar LG, Wallace RB. Changes in electronic cigarette use among adults in the United States, 2014-2016. JAMA 2018;319(19):2039-41.

20. Pepper JK, Ribisl KM, Emery SL, Brewer NT. Reasons for starting and stopping electronic cigarette use. Int J Environ Res Public Health 2014;11(10):10345-61.

21. Primack BA, Shensa A, Sidani JE, Hoffman BL, Soneji S, Sargent JD, et al. Initiation of traditional cigarette smoking after electronic cigarette use among tobacco-naïve US young adults. Am J Med 2018;131(4):443.e1-9.

22. Singh T, Kennedy S, Marynak K, Persoskie A, Melstrom P, King BA. Characteristics of electronic cigarette use among middle and high school students - United States, 2015. MMWR Morb Mortal Wkly Rep 2016;65(50-51):1425-9.

23. Tsai J, Walton K, Coleman BN, Sharapova SR, Johnson SE, Kennedy SM, et al. Reasons for electronic cigarette use among middle and high school students - National Youth Tobacco Survey, United States, 2016. MMWR Morb Mortal Wkly Rep 2018;67(6):196-200.

24. Baeza-Loya S, Viswanath H, Carter A, Molfese DL, Velasquez KM, Baldwin PR, et al. Perceptions about e-cigarette safety may lead to e-smoking during pregnancy. Bull Menninger Clin 2014;78(3):243-52.

25. Farquhar B, Mark K, Terplan M, Chisolm MS. Demystifying electronic cigarette use in pregnancy. J Addict Med 2015; 9(2):157-8.

26. Blumberg SJ, Luke JV. Wireless substitution: early release of estimates from the National Health Interview Survey, January-June 2016. US Department of Health and Human Services, Centers for Disease Control and Prevention; 2016. https://www.cdc.gov/nchs/data/nhis/earlyrelease/ wireless201612.pdf. Accessed February 16, 2018.

27. Connor Gorber S, Schofield-Hurwitz S, Hardt J, Levasseur G, Tremblay $M$. The accuracy of self-reported smoking: a systematic review of the relationship between self-reported and cotinine-assessed smoking status. Nicotine Tob Res 2009; 11(1):12-24.

28. Pierannunzi C, Hu SS, Balluz L. A systematic review of publications assessing reliability and validity of the Behavioral Risk Factor Surveillance System (BRFSS), 2004-2011. BMC Med Res Methodol 2013;13(1):49.
29. Marynak K, Kenemer B, King BA, Tynan MA, MacNeil A, Reimels E. State laws regarding indoor public use, retail sales, and prices of electronic cigarettes - U.S. States, Guam, Puerto Rico, and U.S. Virgin Islands, September 30, 2017. MMWR Morb Mortal Wkly Rep 2017;66(49):1341-6.

\footnotetext{
The opinions expressed by authors contributing to this journal do not necessarily reflect the opinions of the U.S. Department of Health and Human Services, the Public Health Service, the Centers for Disease Control and Prevention, or the authors' affiliated institutions.
} 


\section{Tables}

Table 1. State-Specific Prevalence of Current Cigarette Smoking ${ }^{a}$, Current Smokeless Tobacco Use ${ }^{b}$, and Current E-cigarette Use ${ }^{c}$ Among Adults Aged 18 Years or Older, by Sex - Behavioral Risk Factor Surveillance System, United States, 2016

\begin{tabular}{|c|c|c|c|c|c|c|c|c|c|}
\hline \multirow{2}{*}{$\begin{array}{l}\text { State } \\
\text { (Sample Size) }\end{array}$} & \multicolumn{3}{|c|}{ Cigarette Smoking, \% (95\% Cl) } & \multicolumn{3}{|c|}{ Smokeless Tobacco Use, \% (95\% Cl) } & \multicolumn{3}{|c|}{ E-cigarette Use, \% (95\% Cl) } \\
\hline & Total & Men & Women & Total & Men & Women & Total & Men & Women \\
\hline $\begin{array}{l}\text { All } 50 \text { states and } \\
\text { District of Columbia } \\
\text { median }(\mathrm{N}= \\
477,665)\end{array}$ & $\begin{array}{r}17.1 \\
(15.6-18.5)\end{array}$ & $\begin{array}{r}18.8 \\
(16.0-21.6)\end{array}$ & $\begin{array}{r}15.3 \\
(13.7-16.9)\end{array}$ & $4.0(3.3-4.7)$ & $7.2(5.9-8.5)$ & $1.0(0.5-1.4)$ & $4.7(3.9-5.5)$ & $5.6(4.8-6.4)$ & $3.8(2.6-5.1)$ \\
\hline $\begin{array}{l}\text { Alabama }(n= \\
7,031)\end{array}$ & $\begin{array}{r}21.5 \\
(20.2-22.9)\end{array}$ & $\begin{array}{r}23.3 \\
(21.1-25.5) \\
\end{array}$ & $\begin{array}{r}20.0 \\
(18.2-21.7)\end{array}$ & $5.6(4.8-6.4)$ & $\begin{array}{r}10.5 \\
(8.9-12.1)\end{array}$ & $1.2(0.8-1.6)$ & $5.1(4.3-5.9)$ & $6.5(5.1-7.9)$ & $3.9(3.1-4.7)$ \\
\hline Alaska $(n=2,914)$ & $\begin{array}{r}19.0 \\
(16.7-21.3)\end{array}$ & $\begin{array}{r}21.2 \\
(17.9-24.5)\end{array}$ & $\begin{array}{r}16.6 \\
(13.5-19.8)\end{array}$ & $6.3(4.5-8.0)$ & $\begin{array}{r}10.0 \\
(7.3-12.6)\end{array}$ & - & $4.1(2.9-5.3)$ & $5.1(3.1-7.1)$ & $3.1(2.0-4.2)$ \\
\hline $\begin{array}{l}\text { Arizona }(n= \\
10,952)\end{array}$ & $\begin{array}{r}14.7 \\
(13.5-15.9)\end{array}$ & $\begin{array}{r}17.5 \\
(15.5-19.4)\end{array}$ & $\begin{array}{r}12.1 \\
(10.6-13.6)\end{array}$ & $2.8(2.2-3.3)$ & $4.8(3.8-5.8)$ & $0.9(0.4-1.3)$ & $5.3(4.5-6.1)$ & $6.2(4.9-7.5)$ & $4.4(3.5-5.4)$ \\
\hline $\begin{array}{l}\text { Arkansas }(n= \\
5,298)\end{array}$ & $\begin{array}{r}23.6 \\
(21.3-25.8)\end{array}$ & $\begin{array}{r}24.8 \\
(21.4-28.2)\end{array}$ & $\begin{array}{r}22.5 \\
(19.5-25.5)\end{array}$ & $7.8(6.2-9.3)$ & $\begin{array}{r}13.9 \\
(11.0-16.8)\end{array}$ & $2.0(0.9-3.0)$ & $5.8(4.5-7.1)$ & $7.1(4.9-9.3)$ & $4.6(3.2-6.0)$ \\
\hline $\begin{array}{l}\text { California }(n= \\
11,393)\end{array}$ & $\begin{array}{r}11.0 \\
(10.2-11.7) \\
\end{array}$ & $\begin{array}{r}13.8 \\
(12.6-15.0) \\
\end{array}$ & $8.2(7.3-9.1)$ & $1.7(1.4-2.0)$ & $3.2(2.5-3.8)$ & $0.3(0.1-0.5)$ & $3.2(2.8-3.7)$ & $4.3(3.6-5.1)$ & $2.1(1.6-2.6)$ \\
\hline $\begin{array}{l}\text { Colorado }(n= \\
14,958)\end{array}$ & $\begin{array}{r}15.6 \\
(14.7-16.5)\end{array}$ & $\begin{array}{r}17.7 \\
(16.4-19.0)\end{array}$ & $\begin{array}{r}13.5 \\
(12.4-14.7)\end{array}$ & $3.7(3.2-4.1)$ & $7.0(6.1-7.9)$ & $0.4(0.2-0.6)$ & $5.2(4.7-5.8)$ & $6.1(5.3-7.0)$ & $4.3(3.6-5.1)$ \\
\hline $\begin{array}{l}\text { Connecticut }(n= \\
11,041)\end{array}$ & $\begin{array}{r}13.3 \\
(12.4-14.3)\end{array}$ & $\begin{array}{r}14.8 \\
(13.3-16.4)\end{array}$ & $\begin{array}{r}12.0 \\
(10.7-13.2)\end{array}$ & $2.0(1.5-2.5)$ & $3.4(2.5-4.3)$ & $0.7(0.4-1.1)$ & $4.1(3.4-4.8)$ & $5.3(4.2-6.5)$ & $3.0(2.2-3.7)$ \\
\hline $\begin{array}{l}\text { Delaware }(n= \\
4,057)\end{array}$ & $\begin{array}{r}17.7 \\
(16.0-19.4)\end{array}$ & $\begin{array}{r}19.0 \\
(16.3-21.7)\end{array}$ & $\begin{array}{r}16.4 \\
(14.3-18.6)\end{array}$ & $2.2(1.6-2.9)$ & $3.4(2.2-4.5)$ & $1.2(0.6-1.8)$ & $4.0(3.1-4.9)$ & $5.4(3.9-6.9)$ & $2.8(1.7-3.9)$ \\
\hline $\begin{array}{l}\text { District of Columbia } \\
(n=3,852)\end{array}$ & $\begin{array}{r}14.7 \\
(13.2-16.1)\end{array}$ & $\begin{array}{r}17.7 \\
(15.3-20.1)\end{array}$ & $\begin{array}{r}12.1 \\
(10.4-13.8)\end{array}$ & $1.3(0.7-1.8)$ & $1.8(0.8-2.7)$ & - & $2.4(1.7-3.1)$ & $3.6(2.3-4.9)$ & $1.4(0.7-2.0)$ \\
\hline $\begin{array}{l}\text { Florida }(n= \\
36,955)\end{array}$ & $\begin{array}{r}15.5 \\
(14.7-16.3) \\
\end{array}$ & $\begin{array}{r}17.8 \\
(16.6-19.0) \\
\end{array}$ & $\begin{array}{r}13.3 \\
(12.3-14.3)\end{array}$ & $3.0(2.7-3.4)$ & $4.8(4.2-5.5)$ & $1.3(0.9-1.8)$ & $4.7(4.2-5.2)$ & $5.6(4.8-6.4)$ & $3.9(3.3-4.5)$ \\
\hline Georgia $(n=5,381)$ & $\begin{array}{r}17.9 \\
(16.5-19.3)\end{array}$ & $\begin{array}{r}21.2 \\
(18.9-23.5)\end{array}$ & $\begin{array}{r}14.8 \\
(13.1-16.5)\end{array}$ & $3.8(3.0-4.5)$ & $6.2(4.8-7.7)$ & $1.4(0.9-2.0)$ & $4.8(3.9-5.7)$ & $5.9(4.5-7.4)$ & $3.7(2.7-4.7)$ \\
\hline Hawaii $(n=8,087)$ & $\begin{array}{r}13.1 \\
(12.0-14.2)\end{array}$ & $\begin{array}{r}15.1 \\
(13.4-16.8)\end{array}$ & $\begin{array}{r}10.9 \\
(9.6-12.3)\end{array}$ & $2.4(1.9-2.9)$ & $3.4(2.6-4.2)$ & $1.5(0.9-2.1)$ & $4.3(3.6-5.0)$ & $6.0(4.8-7.1)$ & $2.6(1.9-3.3)$ \\
\hline Idaho $(\mathrm{n}=5,258)$ & $\begin{array}{r}14.5 \\
(13.0-15.9)\end{array}$ & $\begin{array}{r}14.7 \\
(12.5-16.8)\end{array}$ & $\begin{array}{r}14.3 \\
(12.3-16.3)\end{array}$ & $6.1(4.9-7.2)$ & $\begin{array}{r}11.1 \\
(9.0-13.2)\end{array}$ & $1.1(0.5-1.8)$ & $4.6(3.6-5.6)$ & $4.7(3.2-6.2)$ & $4.5(3.2-5.8)$ \\
\hline Illinois $(n=4,764)$ & $\begin{array}{r}15.8 \\
(14.4-17.2)\end{array}$ & $\begin{array}{r}18.7 \\
(16.5-20.8)\end{array}$ & $\begin{array}{r}13.0 \\
(11.3-14.8)\end{array}$ & $2.8(2.1-3.4)$ & $5.0(3.8-6.2)$ & - & $4.3(3.5-5.1)$ & $5.1(3.8-6.4)$ & $3.5(2.5-4.5)$ \\
\hline $\begin{array}{l}\text { Indiana }(n= \\
11,066)\end{array}$ & $\begin{array}{r}21.1 \\
(20.0-22.3)\end{array}$ & $\begin{array}{r}23.6 \\
(21.8-25.4)\end{array}$ & $\begin{array}{r}18.8 \\
(17.3-20.3)\end{array}$ & $4.1(3.5-4.7)$ & $7.6(6.4-8.8)$ & $0.7(0.4-1.0)$ & $4.7(4.1-5.4)$ & $5.0(4.0-5.9)$ & $4.5(3.7-5.4)$ \\
\hline lowa $(n=7,257)$ & $\begin{array}{r}16.7 \\
(15.5-18.0)\end{array}$ & $\begin{array}{r}17.7 \\
(15.9-19.5)\end{array}$ & $\begin{array}{r}15.8 \\
(14.2-17.4)\end{array}$ & $4.6(3.9-5.3)$ & $\begin{array}{r}9.0 \\
(7.6-10.3)\end{array}$ & - & $4.3(3.6-5.0)$ & $4.5(3.5-5.5)$ & $4.1(3.2-5.1)$ \\
\hline $\begin{array}{l}\text { Kansas }(n= \\
12,188)\end{array}$ & $\begin{array}{r}17.2 \\
(16.3-18.1)\end{array}$ & $\begin{array}{r}18.7 \\
(17.3-20.1)\end{array}$ & $\begin{array}{r}15.7 \\
(14.5-16.9)\end{array}$ & $5.9(5.3-6.5)$ & $\begin{array}{r}11.2 \\
(10.1-12.4)\end{array}$ & $0.8(0.4-1.1)$ & $4.9(4.4-5.5)$ & $6.0(5.2-6.9)$ & $3.8(3.1-4.5)$ \\
\hline
\end{tabular}

Abbreviations: $\mathrm{Cl}$, confidence interval; - , estimates not presented because of relative standard error $>30 \%$.

${ }^{a}$ Persons aged $\geq 18$ years who reported having smoked $\geq 100$ cigarettes during their lifetime and smoked every day or some days at the time of survey. Excludes respondents whose smoking status was unknown.

${ }^{\mathrm{b}}$ Persons aged $\geq 18$ years who reported currently using chewing tobacco, snuff, or snus every day or some days at the time of survey. Excludes respondents whose using status was unknown.

${ }^{c}$ Persons aged $\geq 18$ years who reported currently using e-cigarette every day or some days at the time of survey. Excludes respondents whose using status was unknown.

The opinions expressed by authors contributing to this journal do not necessarily reflect the opinions of the U.S. Department of Health and Human Services, the Public Health Service, the Centers for Disease Control and Prevention, or the authors' affiliated institutions. 
(continued)

Table 1. State-Specific Prevalence of Current Cigarette Smoking ${ }^{a}$, Current Smokeless Tobacco Use ${ }^{b}$, and Current E-cigarette Use ${ }^{c}$ Among Adults Aged 18 Years or Older, by Sex - Behavioral Risk Factor Surveillance System, United States, 2016

\begin{tabular}{|c|c|c|c|c|c|c|c|c|c|}
\hline \multirow{2}{*}{$\begin{array}{l}\text { State } \\
\text { (Sample Size) }\end{array}$} & \multicolumn{3}{|c|}{ Cigarette Smoking, \% (95\% Cl) } & \multicolumn{3}{|c|}{ Smokeless Tobacco Use, \% (95\% Cl) } & \multicolumn{3}{|c|}{ E-cigarette Use, \% (95\% Cl) } \\
\hline & Total & Men & Women & Total & Men & Women & Total & Men & Women \\
\hline $\begin{array}{l}\text { Kentucky }(n= \\
10,265)\end{array}$ & $\begin{array}{r}24.5 \\
(23.1-25.8) \\
\end{array}$ & $\begin{array}{r}25.0 \\
(22.9-27.0) \\
\end{array}$ & $\begin{array}{r}24.0 \\
(22.2-25.8) \\
\end{array}$ & $7.4(6.6-8.2)$ & $\begin{array}{r}13.6 \\
(12.1-15.1) \\
\end{array}$ & $1.6(1.1-2.2)$ & $5.6(4.9-6.4)$ & $6.3(5.1-7.5)$ & $5.0(4.1-5.9)$ \\
\hline $\begin{array}{l}\text { Louisiana }(n= \\
5,256)\end{array}$ & $\begin{array}{r}22.8 \\
(20.8-24.8) \\
\end{array}$ & $\begin{array}{r}25.5 \\
(22.4-28.7) \\
\end{array}$ & $\begin{array}{r}20.2 \\
(17.6-22.7) \\
\end{array}$ & $5.1(4.1-6.1)$ & $\begin{array}{r}9.1 \\
(7.1-11.0) \\
\end{array}$ & $1.3(0.7-1.9)$ & $6.0(4.8-7.2)$ & $7.4(5.4-9.3)$ & $4.7(3.3-6.1)$ \\
\hline Maine $(n=10,019)$ & $\begin{array}{r}19.8 \\
(18.4-21.1) \\
\end{array}$ & $\begin{array}{r}21.6 \\
(19.6-23.6) \\
\end{array}$ & $\begin{array}{r}18.0 \\
(16.3-19.8) \\
\end{array}$ & $2.8(2.2-3.4)$ & $4.8(3.7-5.9)$ & $1.0(0.5-1.5)$ & $3.8(3.2-4.5)$ & $5.0(3.9-6.1)$ & $2.7(2.0-3.4)$ \\
\hline $\begin{array}{l}\text { Maryland }(n= \\
18,473)\end{array}$ & $\begin{array}{r}13.7 \\
(12.9-14.5) \\
\end{array}$ & $\begin{array}{r}15.6 \\
(14.3-17.0) \\
\end{array}$ & $\begin{array}{r}11.9 \\
(10.9-12.9) \\
\end{array}$ & $1.6(1.3-1.9)$ & $2.9(2.3-3.5)$ & $0.4(0.2-0.6)$ & $3.2(2.8-3.7)$ & $4.5(3.7-5.3)$ & $2.0(1.6-2.5)$ \\
\hline $\begin{array}{l}\text { Massachusetts }(n= \\
8,415)\end{array}$ & $\begin{array}{r}13.6 \\
(12.6-14.7) \\
\end{array}$ & $\begin{array}{r}15.5 \\
(13.9-17.1) \\
\end{array}$ & $\begin{array}{r}11.9 \\
(10.5-13.3) \\
\end{array}$ & $2.0(1.5-2.4)$ & $3.1(2.3-3.9)$ & $1.0(0.5-1.4)$ & $4.3(3.6-5.1)$ & $5.8(4.6-7.0)$ & $2.9(2.1-3.7)$ \\
\hline $\begin{array}{l}\text { Michigan }(n= \\
12,024)\end{array}$ & $\begin{array}{r}20.4 \\
(19.4-21.4) \\
\end{array}$ & $\begin{array}{r}22.3 \\
(20.8-23.8) \\
\end{array}$ & $\begin{array}{r}18.7 \\
(17.4-20.0) \\
\end{array}$ & $3.6(3.1-4.0)$ & $6.2(5.4-7.1)$ & $1.1(0.7-1.5)$ & $4.9(4.4-5.5)$ & $5.6(4.7-6.5)$ & $4.3(3.6-5.0)$ \\
\hline $\begin{array}{l}\text { Minnesota }(n= \\
16,831)\end{array}$ & $\begin{array}{r}15.2 \\
(14.5-15.9) \\
\end{array}$ & $\begin{array}{r}16.6 \\
(15.5-17.6) \\
\end{array}$ & $\begin{array}{r}13.9 \\
(12.9-14.8) \\
\end{array}$ & $4.3(3.9-4.7)$ & $7.8(7.0-8.5)$ & $0.9(0.7-1.2)$ & $3.8(3.4-4.1)$ & $4.8(4.2-5.4)$ & $2.8(2.3-3.2)$ \\
\hline $\begin{array}{l}\text { Mississippi }(n= \\
5,135)\end{array}$ & $\begin{array}{r}22.7 \\
(21.0-24.4) \\
\end{array}$ & $\begin{array}{r}24.3 \\
(21.7-27.0) \\
\end{array}$ & $\begin{array}{r}21.3 \\
(19.1-23.5) \\
\end{array}$ & $7.2(6.2-8.3)$ & $\begin{array}{r}13.2 \\
(11.2-15.2) \\
\end{array}$ & $1.7(1.0-2.4)$ & $4.7(3.8-5.6)$ & $5.4(3.9-6.9)$ & $4.0(2.9-5.1)$ \\
\hline $\begin{array}{l}\text { Missouri }(n= \\
7,126)\end{array}$ & $\begin{array}{r}22.1 \\
(20.5-23.7) \\
\end{array}$ & $\begin{array}{r}24.5 \\
(22.0-26.9) \\
\end{array}$ & $\begin{array}{r}19.9 \\
(17.8-22.0) \\
\end{array}$ & $4.6(3.8-5.5)$ & $\begin{array}{r}8.8 \\
(7.2-10.4) \\
\end{array}$ & - & $5.0(4.1-5.9)$ & $5.7(4.4-7.1)$ & $4.3(3.2-5.4)$ \\
\hline $\begin{array}{l}\text { Montana }(n= \\
5,971)\end{array}$ & $\begin{array}{r}18.5 \\
(17.0-20.0) \\
\end{array}$ & $\begin{array}{r}19.8 \\
(17.6-22.0) \\
\end{array}$ & $\begin{array}{r}17.3 \\
(15.2-19.4) \\
\end{array}$ & $7.7(6.7-8.8)$ & $\begin{array}{r}14.0 \\
(12.1-16.0) \\
\end{array}$ & $1.5(0.8-2.1)$ & $4.1(3.2-4.9)$ & $4.3(3.1-5.5)$ & $3.8(2.6-5.1)$ \\
\hline $\begin{array}{l}\text { Nebraska }(n= \\
15,183)\end{array}$ & $\begin{array}{r}17.0 \\
(15.9-18.0) \\
\end{array}$ & $\begin{array}{r}18.6 \\
(17.0-20.2) \\
\end{array}$ & $\begin{array}{r}15.4 \\
(14.1-16.7) \\
\end{array}$ & $5.7(5.1-6.2)$ & $\begin{array}{r}10.5 \\
(9.5-11.6) \\
\end{array}$ & $0.9(0.6-1.2)$ & $4.9(4.3-5.6)$ & $5.3(4.4-6.3)$ & $4.5(3.6-5.5)$ \\
\hline Nevada $(n=4,344)$ & $\begin{array}{r}16.5 \\
(14.8-18.1) \\
\end{array}$ & $\begin{array}{r}18.9 \\
(16.3-21.5) \\
\end{array}$ & $\begin{array}{r}14.1 \\
(12.0-16.1) \\
\end{array}$ & $2.5(1.9-3.1)$ & $4.3(3.2-5.4)$ & $0.7(0.3-1.1)$ & $6.0(4.9-7.2)$ & $6.9(5.2-8.7)$ & $5.1(3.7-6.5)$ \\
\hline $\begin{array}{l}\text { New Hampshire ( } \mathrm{n} \\
=6,420)\end{array}$ & $\begin{array}{r}18.0 \\
(16.4-19.6) \\
\end{array}$ & $\begin{array}{r}18.5 \\
(16.3-20.7) \\
\end{array}$ & $\begin{array}{r}17.6 \\
(15.2-19.9) \\
\end{array}$ & $2.2(1.6-2.8)$ & $3.8(2.6-4.9)$ & - & $5.1(4.1-6.1)$ & $6.8(5.2-8.3)$ & $3.5(2.1-4.8)$ \\
\hline $\begin{array}{l}\text { New Jersey }(n= \\
7,652)\end{array}$ & $\begin{array}{r}14.0 \\
(12.6-15.3) \\
\end{array}$ & $\begin{array}{r}14.9 \\
(12.9-17.0) \\
\end{array}$ & $\begin{array}{r}13.1 \\
(11.4-14.8) \\
\end{array}$ & $2.3(1.6-2.9)$ & $3.7(2.4-4.9)$ & $1.0(0.5-1.4)$ & $3.7(2.9-4.5)$ & $4.5(3.2-5.7)$ & $3.0(2.1-3.9)$ \\
\hline $\begin{array}{l}\text { New Mexico }(n= \\
6,024)\end{array}$ & $\begin{array}{r}16.6 \\
(15.1-18.1) \\
\end{array}$ & $\begin{array}{r}19.4 \\
(16.9-21.8) \\
\end{array}$ & $\begin{array}{r}14.0 \\
(12.2-15.8) \\
\end{array}$ & $3.9(3.2-4.6)$ & $7.1(5.8-8.5)$ & $0.9(0.5-1.3)$ & $4.9(3.8-5.9)$ & $5.8(4.1-7.5)$ & $3.9(2.7-5.1)$ \\
\hline $\begin{array}{l}\text { New York }(n= \\
34,190)\end{array}$ & $\begin{array}{r}14.2 \\
(13.4-14.9) \\
\end{array}$ & $\begin{array}{r}16.7 \\
(15.4-17.9)\end{array}$ & $\begin{array}{r}11.9 \\
(11.0-12.8) \\
\end{array}$ & $2.2(1.9-2.5)$ & $3.5(2.9-4.0)$ & $1.1(0.8-1.5)$ & $4.1(3.6-4.6)$ & $5.4(4.6-6.2)$ & $2.9(2.4-3.5)$ \\
\hline $\begin{array}{l}\text { North Carolina }(n= \\
6,536)\end{array}$ & $\begin{array}{r}17.9 \\
(16.7-19.1) \\
\end{array}$ & $\begin{array}{r}20.7 \\
(18.8-22.5) \\
\end{array}$ & $\begin{array}{r}15.3 \\
(13.7-16.9) \\
\end{array}$ & $4.0(3.4-4.7)$ & $7.3(6.1-8.5)$ & $1.0(0.6-1.4)$ & $4.4(3.7-5.1)$ & $5.4(4.3-6.5)$ & $3.4(2.6-4.2)$ \\
\hline $\begin{array}{l}\text { North Dakota }(n= \\
5,742)\end{array}$ & $\begin{array}{r}19.8 \\
(18.3-21.2) \\
\end{array}$ & $\begin{array}{r}22.3 \\
(20.3-24.4) \\
\end{array}$ & $\begin{array}{r}17.1 \\
(15.0-19.2) \\
\end{array}$ & $7.1(6.1-8.1)$ & $\begin{array}{r}12.6 \\
(10.9-14.4)\end{array}$ & $1.4(0.8-2.0)$ & $3.6(2.8-4.5)$ & $3.9(2.8-5.0)$ & $3.4(2.2-4.6)$ \\
\hline Ohio $(n=12,389)$ & $\begin{array}{r}22.5 \\
(21.3-23.8) \\
\end{array}$ & $\begin{array}{r}24.7 \\
(22.7-26.6) \\
\end{array}$ & $\begin{array}{r}20.5 \\
(18.9-22.1) \\
\end{array}$ & $4.7(4.1-5.3)$ & $\begin{array}{r}9.0 \\
(7.7-10.2) \\
\end{array}$ & $0.8(0.4-1.1)$ & $5.7(5.0-6.4)$ & $5.8(4.7-6.9)$ & $5.6(4.6-6.6)$ \\
\hline $\begin{array}{l}\text { Oklahoma }(n= \\
6,925)\end{array}$ & $\begin{array}{r}19.6 \\
(18.2-21.0)\end{array}$ & $\begin{array}{r}21.4 \\
(19.1-23.7)\end{array}$ & $\begin{array}{r}17.9 \\
(16.1-19.6)\end{array}$ & $6.0(5.2-6.9)$ & $\begin{array}{r}11.4 \\
(9.7-13.1)\end{array}$ & $0.9(0.5-1.3)$ & $6.7(5.7-7.7)$ & $7.9(6.1-9.6)$ & $5.5(4.5-6.5)$ \\
\hline
\end{tabular}

Abbreviations: $\mathrm{Cl}$, confidence interval; -, estimates not presented because of relative standard error $>30 \%$.

a Persons aged $\geq 18$ years who reported having smoked $\geq 100$ cigarettes during their lifetime and smoked every day or some days at the time of survey. Excludes respondents whose smoking status was unknown.

${ }^{\mathrm{b}}$ Persons aged $\geq 18$ years who reported currently using chewing tobacco, snuff, or snus every day or some days at the time of survey. Excludes respondents whose using status was unknown.

${ }^{c}$ Persons aged $\geq 18$ years who reported currently using e-cigarette every day or some days at the time of survey. Excludes respondents whose using status was unknown.

(continued on next page)

The opinions expressed by authors contributing to this journal do not necessarily reflect the opinions of the U.S. Department of Health and Human Services, the Public Health Service, the Centers for Disease Control and Prevention, or the authors' affiliated institutions. 
(continued)

Table 1. State-Specific Prevalence of Current Cigarette Smoking ${ }^{a}$, Current Smokeless Tobacco Use ${ }^{b}$, and Current E-cigarette Use ${ }^{c}$ Among Adults Aged 18 Years or Older, by Sex - Behavioral Risk Factor Surveillance System, United States, 2016

\begin{tabular}{|c|c|c|c|c|c|c|c|c|c|}
\hline \multirow{2}{*}{$\begin{array}{l}\text { State } \\
\text { (Sample Size) }\end{array}$} & \multicolumn{3}{|c|}{ Cigarette Smoking, \% (95\% Cl) } & \multicolumn{3}{|c|}{ Smokeless Tobacco Use, \% (95\% Cl) } & \multicolumn{3}{|c|}{ E-cigarette Use, \% (95\% Cl) } \\
\hline & Total & Men & Women & Total & Men & Women & Total & Men & Women \\
\hline Oregon $(n=5,439)$ & $\begin{array}{r}16.2 \\
(14.9-17.5) \\
\end{array}$ & $\begin{array}{r}18.1 \\
(16.1-20.1) \\
\end{array}$ & $\begin{array}{r}14.4 \\
(12.8-16.0) \\
\end{array}$ & $4.0(3.3-4.7)$ & $7.2(5.9-8.5)$ & $0.9(0.5-1.4)$ & $4.4(3.7-5.2)$ & $5.8(4.5-7.1)$ & $3.1(2.3-3.9)$ \\
\hline $\begin{array}{l}\text { Pennsylvania }(n= \\
6,810)\end{array}$ & $\begin{array}{r}18.0 \\
(16.7-19.2) \\
\end{array}$ & $\begin{array}{r}20.1 \\
(18.1-22.0) \\
\end{array}$ & $\begin{array}{r}16.0 \\
(14.4-17.6) \\
\end{array}$ & $4.1(3.4-4.7)$ & $7.9(6.7-9.1)$ & - & $4.2(3.5-4.8)$ & $4.7(3.7-5.7)$ & $3.6(2.8-4.4)$ \\
\hline $\begin{array}{l}\text { Rhode Island }(\mathrm{n}= \\
5,457)\end{array}$ & $\begin{array}{r}14.4 \\
(13.0-15.8) \\
\end{array}$ & $\begin{array}{r}16.9 \\
(14.6-19.2) \\
\end{array}$ & $\begin{array}{r}12.2 \\
(10.6-13.8) \\
\end{array}$ & $1.5(1.0-2.0)$ & $2.8(1.8-3.7)$ & - & $4.5(3.5-5.4)$ & $5.9(4.2-7.7)$ & $3.2(2.2-4.1)$ \\
\hline $\begin{array}{l}\text { South Carolina }(n= \\
11,236)\end{array}$ & $\begin{array}{r}20.0 \\
(18.9-21.2) \\
\end{array}$ & $\begin{array}{r}22.9 \\
(21.0-24.7) \\
\end{array}$ & $\begin{array}{r}17.4 \\
(16.0-18.8) \\
\end{array}$ & $3.7(3.1-4.3)$ & $6.8(5.7-8.0)$ & $0.9(0.6-1.2)$ & $4.8(4.1-5.4)$ & $5.2(4.2-6.2)$ & $4.3(3.5-5.1)$ \\
\hline $\begin{array}{l}\text { South Dakota }(\mathrm{n}= \\
5,767)\end{array}$ & $\begin{array}{r}18.1 \\
(16.3-20.0) \\
\end{array}$ & $\begin{array}{r}21.1 \\
(18.2-24.1) \\
\end{array}$ & $\begin{array}{r}15.1 \\
(12.9-17.3) \\
\end{array}$ & $5.9(4.7-7.0)$ & $\begin{array}{r}10.9 \\
(8.7-13.1) \\
\end{array}$ & - & $2.9(2.1-3.7)$ & $3.3(2.1-4.5)$ & $2.5(1.5-3.5)$ \\
\hline $\begin{array}{l}\text { Tennessee }(n= \\
6,167)\end{array}$ & $\begin{array}{r}22.1 \\
(20.5-23.7) \\
\end{array}$ & $\begin{array}{r}23.9 \\
(21.4-26.4) \\
\end{array}$ & $\begin{array}{r}20.4 \\
(18.4-22.3) \\
\end{array}$ & $6.8(5.8-7.7)$ & $\begin{array}{r}12.4 \\
(10.6-14.3) \\
\end{array}$ & $1.5(0.9-2.0)$ & $5.7(4.8-6.6)$ & $7.3(5.7-8.9)$ & $4.2(3.2-5.2)$ \\
\hline Texas $(n=11,709)$ & $\begin{array}{r}14.3 \\
(13.1-15.5) \\
\end{array}$ & $\begin{array}{r}17.3 \\
(15.4-19.2) \\
\end{array}$ & $\begin{array}{r}11.3 \\
(9.8-12.7) \\
\end{array}$ & $4.3(3.6-5.1)$ & $7.4(6.0-8.7)$ & $1.3(0.7-2.0)$ & $4.7(3.9-5.5)$ & $6.7(5.3-8.2)$ & $2.7(2.0-3.5)$ \\
\hline Utah $(n=10,988)$ & $8.8(8.0-9.6)$ & $\begin{array}{r}10.4 \\
(9.1-11.7) \\
\end{array}$ & $7.1(6.1-8.1)$ & $3.4(2.9-4.0)$ & $5.9(5.0-6.9)$ & $0.9(0.5-1.3)$ & $5.1(4.4-5.7)$ & $5.8(4.9-6.8)$ & $4.3(3.4-5.2)$ \\
\hline $\begin{array}{l}\text { Vermont }(n= \\
6,540)\end{array}$ & $\begin{array}{r}17.0 \\
(15.6-18.4) \\
\end{array}$ & $\begin{array}{r}19.5 \\
(17.3-21.7) \\
\end{array}$ & $\begin{array}{r}14.7 \\
(12.9-16.5) \\
\end{array}$ & $3.1(2.5-3.8)$ & $5.9(4.5-7.2)$ & - & $3.4(2.6-4.2)$ & $4.5(3.2-5.9)$ & $2.3(1.5-3.1)$ \\
\hline Virginia $(n=9,002)$ & $\begin{array}{r}15.3 \\
(14.3-16.3) \\
\end{array}$ & $\begin{array}{r}17.0 \\
(15.4-18.5) \\
\end{array}$ & $\begin{array}{r}13.7 \\
(12.5-15.0) \\
\end{array}$ & $3.7(3.2-4.2)$ & $6.6(5.7-7.6)$ & $0.9(0.6-1.3)$ & $4.9(4.3-5.6)$ & $6.1(5.1-7.2)$ & $3.7(2.9-4.5)$ \\
\hline $\begin{array}{l}\text { Washington }(n= \\
14,259)\end{array}$ & $\begin{array}{r}13.9 \\
(13.1-14.7) \\
\end{array}$ & $\begin{array}{r}16.0 \\
(14.7-17.2) \\
\end{array}$ & $\begin{array}{r}11.9 \\
(10.9-13.0) \\
\end{array}$ & $3.5(3.0-3.9)$ & $6.3(5.5-7.1)$ & $0.7(0.4-1.0)$ & $5.3(4.7-5.8)$ & $6.7(5.8-7.5)$ & $3.9(3.2-4.5)$ \\
\hline $\begin{array}{l}\text { West Virginia }(n= \\
7,151)\end{array}$ & $\begin{array}{r}24.8 \\
(23.6-26.1) \\
\end{array}$ & $\begin{array}{r}25.8 \\
(23.9-27.7) \\
\end{array}$ & $\begin{array}{r}23.9 \\
(22.2-25.5) \\
\end{array}$ & $8.5(7.7-9.4)$ & $\begin{array}{r}15.9 \\
(14.3-17.5) \\
\end{array}$ & $1.5(1.0-2.0)$ & $4.7(4.0-5.3)$ & $4.9(3.9-5.9)$ & $4.4(3.5-5.3)$ \\
\hline $\begin{array}{l}\text { Wisconsin }(n= \\
5,271)\end{array}$ & $\begin{array}{r}17.1 \\
(15.6-18.5) \\
\end{array}$ & $\begin{array}{r}18.0 \\
(15.8-20.2) \\
\end{array}$ & $\begin{array}{r}16.2 \\
(14.1-18.2) \\
\end{array}$ & $4.4(3.6-5.2)$ & $8.0(6.5-9.6)$ & $0.9(0.4-1.4)$ & $5.3(4.3-6.3)$ & $6.7(5.0-8.3)$ & $4.0(2.9-5.1)$ \\
\hline $\begin{array}{l}\text { Wyoming }(n= \\
4,497)\end{array}$ & $\begin{array}{r}18.9 \\
(17.0-20.9) \\
\end{array}$ & $\begin{array}{r}18.8 \\
(16.0-21.6)\end{array}$ & $\begin{array}{r}19.1 \\
(16.4-21.9)\end{array}$ & $\begin{array}{r}9.8 \\
(8.2-11.3) \\
\end{array}$ & $\begin{array}{r}17.0 \\
(14.3-19.8)\end{array}$ & $2.3(1.0-3.6)$ & $5.5(4.3-6.8)$ & $6.1(4.3-7.8)$ & $5.0(3.3-6.7)$ \\
\hline
\end{tabular}

Abbreviations: $\mathrm{Cl}$, confidence interval; -, estimates not presented because of relative standard error $>30 \%$.

${ }^{a}$ Persons aged $\geq 18$ years who reported having smoked $\geq 100$ cigarettes during their lifetime and smoked every day or some days at the time of survey. Excludes respondents whose smoking status was unknown.

${ }^{b}$ Persons aged $\geq 18$ years who reported currently using chewing tobacco, snuff, or snus every day or some days at the time of survey. Excludes respondents whose using status was unknown.

${ }^{c}$ Persons aged $\geq 18$ years who reported currently using e-cigarette every day or some days at the time of survey. Excludes respondents whose using status was unknown.

The opinions expressed by authors contributing to this journal do not necessarily reflect the opinions of the U.S. Department of Health and Human Services, the Public Health Service, the Centers for Disease Control and Prevention, or the authors' affiliated institutions. 
Table 2. State-Specific Prevalence of Ever E-cigarette Use ${ }^{a}$ Among Adults Aged 18 Years or Older, by Sex and Race/Ethnicity - Behavioral Risk Factor Surveillance System, United States, 2016

\begin{tabular}{|c|c|c|c|c|c|c|c|}
\hline \multirow[b]{2}{*}{ State } & \multirow[b]{2}{*}{$\begin{array}{l}\text { Total \% } \\
(95 \% \mathrm{Cl})\end{array}$} & \multicolumn{2}{|c|}{ Sex } & \multicolumn{4}{|c|}{ Race/Ethnicity } \\
\hline & & $\begin{array}{c}\text { Men \% } \\
(95 \% \mathrm{Cl})\end{array}$ & $\begin{array}{l}\text { Women \% } \\
(95 \% \mathrm{Cl})\end{array}$ & $\begin{array}{c}\text { Non-Hispanic White } \\
\%(95 \% \mathrm{Cl})\end{array}$ & $\begin{array}{c}\text { Non-Hispanic Black } \\
\%(95 \% \mathrm{Cl})\end{array}$ & $\begin{array}{l}\text { Hispanic \% } \\
(95 \% \mathrm{Cl})\end{array}$ & $\begin{array}{l}\text { Non-Hispanic Other } \\
\%(95 \% \mathrm{Cl})\end{array}$ \\
\hline $\begin{array}{l}\text { All } 50 \text { states and } \\
\text { District of Columbia } \\
\text { median }\end{array}$ & $\begin{array}{r}22.1 \\
(20.4-23.7)\end{array}$ & $\begin{array}{r}24.8 \\
(21.9-27.8)\end{array}$ & $\begin{array}{r}18.6 \\
(16.6-20.7)\end{array}$ & $22.4(20.7-24.1)$ & $21.9(17.3-26.5)$ & $20.8(18.0-23.6)$ & $26.3(18.8-33.8)$ \\
\hline Alabama & $\begin{array}{r}24.7 \\
(23.2-26.2) \\
\end{array}$ & $\begin{array}{r}27.7 \\
(25.3-30.1) \\
\end{array}$ & $\begin{array}{r}21.9 \\
(20.1-23.7) \\
\end{array}$ & $26.3(24.4-28.1)$ & $17.4(15.0-19.8)$ & $30.5(18.5-42.6)$ & $39.8(30.8-48.8)$ \\
\hline Alaska & $\begin{array}{r}24.7 \\
(22.0-27.4)\end{array}$ & $\begin{array}{r}30.4 \\
(26.2-34.5) \\
\end{array}$ & $\begin{array}{r}18.4 \\
(15.3-21.5)\end{array}$ & $21.8(19.0-24.6)$ & - & $43.4(27.0-59.8)$ & $30.9(24.6-37.2)$ \\
\hline Arizona & $\begin{array}{r}23.2 \\
(21.7-24.7) \\
\end{array}$ & $\begin{array}{r}27.4 \\
(25.0-29.8) \\
\end{array}$ & $\begin{array}{r}19.2 \\
(17.3-21.1) \\
\end{array}$ & $23.6(21.8-25.3)$ & $29.6(20.6-38.6)$ & $21.8(18.1-25.4)$ & $22.5(17.8-27.2)$ \\
\hline Arkansas & $\begin{array}{r}28.4 \\
(25.9-30.9)\end{array}$ & $\begin{array}{r}30.0 \\
(26.3-33.7)\end{array}$ & $\begin{array}{r}26.9 \\
(23.5-30.2)\end{array}$ & $30.1(27.4-32.9)$ & $17.1(10.9-23.3)$ & $26.6(13.8-39.4)$ & $34.4(21.6-47.3)$ \\
\hline California & $\begin{array}{r}20.5 \\
(19.5-21.5) \\
\end{array}$ & $\begin{array}{r}25.2 \\
(23.6-26.7) \\
\end{array}$ & $\begin{array}{r}16.0 \\
(14.7-17.3) \\
\end{array}$ & $23.1(21.6-24.6)$ & $24.3(19.3-29.4)$ & $18.7(17.0-20.4)$ & $16.3(13.8-18.8)$ \\
\hline Colorado & $\begin{array}{r}23.1 \\
(22.0-24.1) \\
\end{array}$ & $\begin{array}{r}25.7 \\
(24.1-27.2) \\
\end{array}$ & $\begin{array}{r}20.6 \\
(19.1-22.0) \\
\end{array}$ & $22.7(21.5-23.9)$ & $26.4(19.8-33.0)$ & $23.1(20.5-25.7)$ & $27.7(22.4-33.1)$ \\
\hline Connecticut & $\begin{array}{r}17.8 \\
(16.6-19.0) \\
\end{array}$ & $\begin{array}{r}21.4 \\
(19.5-23.3) \\
\end{array}$ & $\begin{array}{r}14.4 \\
(13.0-15.8) \\
\end{array}$ & $17.9(16.5-19.3)$ & $14.9(11.1-18.7)$ & $20.0(16.5-23.5)$ & $18.8(13.8-23.8)$ \\
\hline Delaware & $\begin{array}{r}19.0 \\
(17.1-20.9) \\
\end{array}$ & $\begin{array}{r}21.3 \\
(18.6-24.1) \\
\end{array}$ & $\begin{array}{r}16.9 \\
(14.3-19.6) \\
\end{array}$ & $20.0(17.6-22.4)$ & $15.8(11.7-19.9)$ & $12.5(7.2-17.7)$ & $24.2(16.2-32.1)$ \\
\hline District of Columbia & $\begin{array}{r}16.2 \\
(14.5-17.9) \\
\end{array}$ & $\begin{array}{r}20.5 \\
(17.7-23.3) \\
\end{array}$ & $\begin{array}{r}12.5 \\
(10.5-14.5) \\
\end{array}$ & $16.4(13.4-19.4)$ & $15.5(13.5-17.5)$ & $15.8(9.4-22.2)$ & $22.4(14.8-30.1)$ \\
\hline Florida & $\begin{array}{r}20.3 \\
(19.4-21.2) \\
\end{array}$ & $\begin{array}{r}23.2 \\
(21.8-24.6) \\
\end{array}$ & $\begin{array}{r}17.6 \\
(16.4-18.8) \\
\end{array}$ & $22.7(21.6-23.8)$ & $15.8(13.1-18.5)$ & $17.5(15.3-19.7)$ & $16.0(12.7-19.3)$ \\
\hline Georgia & $\begin{array}{r}20.8 \\
(19.3-22.4) \\
\end{array}$ & $\begin{array}{r}23.2 \\
(20.8-25.7) \\
\end{array}$ & $\begin{array}{r}18.6 \\
(16.6-20.7) \\
\end{array}$ & $23.6(21.5-25.7)$ & $18.2(15.3-21.1)$ & $13.9(9.0-18.8)$ & $20.2(13.1-27.4)$ \\
\hline Hawaii & $\begin{array}{r}22.2 \\
(20.8-23.6) \\
\end{array}$ & $\begin{array}{r}26.1 \\
(23.9-28.2) \\
\end{array}$ & $\begin{array}{r}18.3 \\
(16.5-20.0) \\
\end{array}$ & $21.4(18.6-24.3)$ & $26.6(12.8-40.4)$ & $37.1(31.3-43.0)$ & $20.3(18.7-21.9)$ \\
\hline Idaho & $\begin{array}{r}22.5 \\
(20.7-24.4) \\
\end{array}$ & $\begin{array}{r}24.3 \\
(21.4-27.3) \\
\end{array}$ & $\begin{array}{r}20.8 \\
(18.4-23.1) \\
\end{array}$ & $22.2(20.2-24.1)$ & - & $20.4(13.6-27.3)$ & $38.1(26.9-49.3)$ \\
\hline Illinois & $\begin{array}{r}21.2 \\
(19.6-22.8) \\
\end{array}$ & $\begin{array}{r}26.2 \\
(23.7-28.7) \\
\end{array}$ & $\begin{array}{r}16.5 \\
(14.5-18.4) \\
\end{array}$ & $21.9(19.9-23.8)$ & $22.8(18.2-27.4)$ & $16.7(12.7-20.7)$ & $20.9(14.6-27.3)$ \\
\hline Indiana & $\begin{array}{r}24.5 \\
(23.1-25.8) \\
\end{array}$ & $\begin{array}{r}26.9 \\
(24.9-29.0)\end{array}$ & $\begin{array}{r}22.1 \\
(20.4-23.8) \\
\end{array}$ & $24.6(23.2-26.0)$ & $22.9(17.9-27.9)$ & $19.0(13.9-24.2)$ & $30.5(22.4-38.5)$ \\
\hline lowa & $\begin{array}{r}19.2 \\
(17.8-20.5) \\
\end{array}$ & $\begin{array}{r}22.6 \\
(20.5-24.7) \\
\end{array}$ & $\begin{array}{r}15.8 \\
(14.1-17.5) \\
\end{array}$ & $19.0(17.6-20.4)$ & $21.8(10.3-33.2)$ & $17.8(10.6-24.9)$ & $24.2(15.5-32.9)$ \\
\hline Kansas & $\begin{array}{r}24.2 \\
(23.1-25.3) \\
\end{array}$ & $\begin{array}{r}27.5 \\
(25.8-29.1) \\
\end{array}$ & $\begin{array}{r}20.9 \\
(19.5-22.3) \\
\end{array}$ & $23.3(22.2-24.4)$ & $27.2(21.1-33.3)$ & $22.9(18.8-27.1)$ & $36.1(30.3-42.0)$ \\
\hline Kentucky & $\begin{array}{r}26.9 \\
(25.5-28.4) \\
\end{array}$ & $\begin{array}{r}27.9 \\
(25.7-30.0) \\
\end{array}$ & $\begin{array}{r}26.1 \\
(24.2-27.9) \\
\end{array}$ & $27.0(25.5-28.4)$ & $21.9(17.3-26.5)$ & $36.8(23.2-50.3)$ & $33.6(25.3-41.8)$ \\
\hline Louisiana & $\begin{array}{r}24.5 \\
(22.4-26.6) \\
\end{array}$ & $\begin{array}{r}27.7 \\
(24.4-30.9) \\
\end{array}$ & $\begin{array}{r}21.5 \\
(18.8-24.2) \\
\end{array}$ & $27.9(25.3-30.6)$ & $16.2(12.6-19.8)$ & $27.6(15.0-40.2)$ & $32.7(21.5-43.8)$ \\
\hline Maine & $\begin{array}{r}21.4 \\
(20.0-22.8)\end{array}$ & $\begin{array}{r}24.5 \\
(22.3-26.6)\end{array}$ & $\begin{array}{r}18.5 \\
(16.7-20.4)\end{array}$ & $21.0(19.5-22.4)$ & - & - & $40.7(31.8-49.6)$ \\
\hline
\end{tabular}

Abbreviations: $\mathrm{Cl}$, confidence interval; - , estimates not presented because of relative standard error $>30 \%$.

${ }^{a}$ Persons aged $\geq 18$ years who reported having ever used an e-cigarette or other electronic "vaping" product, even just 1 time, during their lifetime. Excludes respondents whose ever using status was unknown. 
(continued)

Table 2. State-Specific Prevalence of Ever E-cigarette Use ${ }^{a}$ Among Adults Aged 18 Years or Older, by Sex and Race/Ethnicity - Behavioral Risk Factor Surveillance System, United States, 2016

\begin{tabular}{|c|c|c|c|c|c|c|c|}
\hline \multirow[b]{2}{*}{ State } & \multirow[b]{2}{*}{$\begin{array}{l}\text { Total \% } \\
(95 \% \mathrm{Cl})\end{array}$} & \multicolumn{2}{|c|}{ Sex } & \multicolumn{4}{|c|}{ Race/Ethnicity } \\
\hline & & $\begin{array}{c}\text { Men \% } \\
(95 \% \mathrm{Cl})\end{array}$ & $\begin{array}{l}\text { Women \% } \\
(95 \% \mathrm{Cl})\end{array}$ & $\begin{array}{c}\text { Non-Hispanic White } \\
\%(95 \% \mathrm{Cl})\end{array}$ & $\begin{array}{c}\text { Non-Hispanic Black } \\
\%(95 \% \mathrm{Cl})\end{array}$ & $\begin{array}{l}\text { Hispanic \% } \\
(95 \% \mathrm{Cl})\end{array}$ & $\begin{array}{c}\text { Non-Hispanic Other } \\
\%(95 \% \mathrm{Cl})\end{array}$ \\
\hline Maryland & $\begin{array}{r}18.1 \\
(17.1-19.1) \\
\end{array}$ & $\begin{array}{r}20.9 \\
(19.3-22.4) \\
\end{array}$ & $\begin{array}{r}15.6 \\
(14.3-16.8)\end{array}$ & $20.4(19.1-21.7)$ & $16.0(14.0-17.9)$ & $15.5(11.8-19.2)$ & $14.2(10.9-17.6)$ \\
\hline Massachusetts & $\begin{array}{r}18.5 \\
(17.3-19.7)\end{array}$ & $\begin{array}{r}21.4 \\
(19.5-23.3)\end{array}$ & $\begin{array}{r}15.7 \\
(14.1-17.4)\end{array}$ & $18.9(17.4-20.3)$ & $16.7(11.7-21.7)$ & $15.3(11.9-18.6)$ & $18.8(13.9-23.7)$ \\
\hline Michigan & $\begin{array}{r}23.0 \\
(22.0-24.1) \\
\end{array}$ & $\begin{array}{r}25.8 \\
(24.2-27.4) \\
\end{array}$ & $\begin{array}{r}20.5 \\
(19.1-21.8) \\
\end{array}$ & $23.1(21.9-24.3)$ & $20.9(17.8-23.9)$ & $27.4(21.2-33.5)$ & $24.9(20.2-29.6)$ \\
\hline Minnesota & $\begin{array}{r}19.6 \\
(18.8-20.4) \\
\end{array}$ & $\begin{array}{r}22.5 \\
(21.3-23.7) \\
\end{array}$ & $\begin{array}{r}16.8 \\
(15.7-17.8) \\
\end{array}$ & $19.2(18.3-20.0)$ & $23.4(18.7-28.0)$ & $15.4(12.0-18.8)$ & $24.4(20.6-28.1)$ \\
\hline Mississippi & $\begin{array}{r}22.2 \\
(20.5-24.0) \\
\end{array}$ & $\begin{array}{r}25.1 \\
(22.3-27.8) \\
\end{array}$ & $\begin{array}{r}19.6 \\
(17.4-21.8) \\
\end{array}$ & $25.8(23.4-28.1)$ & $14.4(12.1-16.8)$ & $29.1(14.4-43.8)$ & $42.7(27.9-57.5)$ \\
\hline Missouri & $\begin{array}{r}25.2 \\
(23.5-27.0) \\
\end{array}$ & $\begin{array}{r}27.9 \\
(25.3-30.4) \\
\end{array}$ & $\begin{array}{r}22.7 \\
(20.3-25.1) \\
\end{array}$ & $25.3(23.4-27.1)$ & $21.9(15.6-28.3)$ & $26.6(14.3-38.9)$ & $34.3(25.0-43.5)$ \\
\hline Montana & $\begin{array}{r}21.8 \\
(20.2-23.5) \\
\end{array}$ & $\begin{array}{r}24.4 \\
(21.9-26.8) \\
\end{array}$ & $\begin{array}{r}19.3 \\
(17.0-21.6) \\
\end{array}$ & $20.7(18.9-22.4)$ & - & $28.2(16.7-39.8)$ & $34.2(27.6-40.7)$ \\
\hline Nebraska & $\begin{array}{r}22.6 \\
(21.4-23.8) \\
\end{array}$ & $\begin{array}{r}25.1 \\
(23.3-26.9) \\
\end{array}$ & $\begin{array}{r}20.2 \\
(18.6-21.8) \\
\end{array}$ & $22.2(20.9-23.4)$ & $27.0(18.1-35.9)$ & $17.9(14.2-21.7)$ & $35.8(28.4-43.2)$ \\
\hline Nevada & $\begin{array}{r}23.2 \\
(21.2-25.1) \\
\end{array}$ & $\begin{array}{r}26.4 \\
(23.5-29.2) \\
\end{array}$ & $\begin{array}{r}20.0 \\
(17.4-22.5)\end{array}$ & $24.3(21.8-26.8)$ & $26.0(18.2-33.7)$ & $17.6(14.3-21.0)$ & $27.8(20.5-35.1)$ \\
\hline New Hampshire & $\begin{array}{r}21.2 \\
(19.4-22.9) \\
\end{array}$ & $\begin{array}{r}24.7 \\
(22.1-27.3) \\
\end{array}$ & $\begin{array}{r}17.8 \\
(15.5-20.1) \\
\end{array}$ & $20.7(19.0-22.5)$ & - & $22.9(9.5-36.4)$ & $30.4(20.4-40.3)$ \\
\hline New Jersey & $\begin{array}{r}18.2 \\
(16.6-19.8) \\
\end{array}$ & $\begin{array}{r}21.6 \\
(19.0-24.2) \\
\end{array}$ & $\begin{array}{r}15.0 \\
(13.2-16.9) \\
\end{array}$ & $20.2(18.0-22.3)$ & $20.7(15.7-25.7)$ & $13.3(10.2-16.3)$ & $14.5(9.6-19.3)$ \\
\hline New Mexico & $\begin{array}{r}25.5 \\
(23.7-27.4) \\
\end{array}$ & $\begin{array}{r}29.1 \\
(26.2-32.0) \\
\end{array}$ & $\begin{array}{r}22.1 \\
(19.7-24.5) \\
\end{array}$ & $23.4(21.0-25.9)$ & $38.5(19.0-58.0)$ & $27.6(24.5-30.8)$ & $23.4(18.1-28.8)$ \\
\hline New York & $\begin{array}{r}19.7 \\
(18.8-20.7) \\
\end{array}$ & $\begin{array}{r}24.0 \\
(22.5-25.4) \\
\end{array}$ & $\begin{array}{r}15.9 \\
(14.7-17.0) \\
\end{array}$ & $21.3(20.2-22.5)$ & $17.6(14.9-20.3)$ & $18.8(16.5-21.2)$ & $15.4(12.1-18.7)$ \\
\hline North Carolina & $\begin{array}{r}21.2 \\
(19.9-22.5) \\
\end{array}$ & $\begin{array}{r}24.2 \\
(22.2-26.2) \\
\end{array}$ & $\begin{array}{r}18.4 \\
(16.7-20.2) \\
\end{array}$ & $22.4(20.7-24.1)$ & $19.7(16.8-22.6)$ & $12.4(8.7-16.2)$ & $23.0(16.8-29.2)$ \\
\hline North Dakota & $\begin{array}{r}22.1 \\
(20.4-23.7) \\
\end{array}$ & $\begin{array}{r}24.6 \\
(22.3-26.9) \\
\end{array}$ & $\begin{array}{r}19.4 \\
(17.0-21.7) \\
\end{array}$ & $20.4(18.8-22.1)$ & $26.2(11.3-41.1)$ & $36.9(20.7-53.2)$ & $36.0(28.3-43.8)$ \\
\hline Ohio & $\begin{array}{r}25.0 \\
(23.7-26.4) \\
\end{array}$ & $\begin{array}{r}27.0 \\
(25.0-29.0) \\
\end{array}$ & $\begin{array}{r}23.2 \\
(21.5-25.0) \\
\end{array}$ & $24.7(23.3-26.2)$ & $25.5(21.0-30.0)$ & $25.9(17.2-34.6)$ & $31.3(24.2-38.4)$ \\
\hline Oklahoma & $\begin{array}{r}27.9 \\
(26.3-29.5) \\
\end{array}$ & $\begin{array}{r}30.1 \\
(27.6-32.7) \\
\end{array}$ & $\begin{array}{r}25.7 \\
(23.7-27.7) \\
\end{array}$ & $27.0(25.2-28.8)$ & $26.0(19.3-32.8)$ & $25.6(19.2-31.9)$ & $33.8(29.1-38.5)$ \\
\hline Oregon & $\begin{array}{r}20.8 \\
(19.4-22.2) \\
\end{array}$ & $\begin{array}{r}23.2 \\
(21.1-25.3) \\
\end{array}$ & $\begin{array}{r}18.5 \\
(16.6-20.3) \\
\end{array}$ & $20.7(19.2-22.2)$ & $30.2(13.3-47.0)$ & $17.2(12.3-22.2)$ & $24.3(18.5-30.2)$ \\
\hline Pennsylvania & $\begin{array}{r}21.2 \\
(19.8-22.5) \\
\end{array}$ & $\begin{array}{r}24.0 \\
(21.9-26.0) \\
\end{array}$ & $\begin{array}{r}18.5 \\
(16.7-20.3) \\
\end{array}$ & $20.6(19.1-22.1)$ & $21.2(16.6-25.8)$ & $28.8(21.2-36.4)$ & $19.6(14.2-24.9)$ \\
\hline Rhode Island & $\begin{array}{r}20.9 \\
(19.1-22.7) \\
\end{array}$ & $\begin{array}{r}24.8 \\
(21.9-27.8) \\
\end{array}$ & $\begin{array}{r}17.3 \\
(15.1-19.4) \\
\end{array}$ & $20.8(18.7-22.8)$ & $22.2(13.5-30.9)$ & $20.6(15.2-26.0)$ & $22.3(14.0-30.5)$ \\
\hline South Carolina & $\begin{array}{r}22.9 \\
(21.6-24.1) \\
\end{array}$ & $\begin{array}{r}26.6 \\
(24.6-28.6) \\
\end{array}$ & $\begin{array}{r}19.4 \\
(17.9-20.9) \\
\end{array}$ & $23.9(22.4-25.4)$ & $18.2(15.7-20.6)$ & $29.1(20.8-37.4)$ & $30.2(23.6-36.7)$ \\
\hline South Dakota & 20.3 & 23.9 & 16.7 & $18.8(16.8-20.7)$ & - & - & $35.6(27.4-43.9)$ \\
\hline
\end{tabular}

Abbreviations: $\mathrm{Cl}$, confidence interval; - , estimates not presented because of relative standard error $>30 \%$.

a Persons aged $\geq 18$ years who reported having ever used an e-cigarette or other electronic "vaping" product, even just 1 time, during their lifetime. Excludes respondents whose ever using status was unknown. 
(continued)

Table 2. State-Specific Prevalence of Ever E-cigarette Use ${ }^{a}$ Among Adults Aged 18 Years or Older, by Sex and Race/Ethnicity - Behavioral Risk Factor Surveillance System, United States, 2016

\begin{tabular}{|c|c|c|c|c|c|c|c|}
\hline \multirow[b]{2}{*}{ State } & \multirow[b]{2}{*}{$\begin{array}{c}\text { Total \% } \\
(95 \% \mathrm{Cl})\end{array}$} & \multicolumn{2}{|c|}{ Sex } & \multicolumn{4}{|c|}{ Race/Ethnicity } \\
\hline & & $\begin{array}{c}\text { Men \% } \\
(95 \% \mathrm{Cl})\end{array}$ & $\begin{array}{l}\text { Women \% } \\
(95 \% \mathrm{Cl})\end{array}$ & $\begin{array}{c}\text { Non-Hispanic White } \\
\%(95 \% \mathrm{Cl})\end{array}$ & $\begin{array}{c}\text { Non-Hispanic Black } \\
\%(95 \% \mathrm{Cl})\end{array}$ & $\begin{array}{l}\text { Hispanic \% } \\
(95 \% \mathrm{Cl})\end{array}$ & $\begin{array}{c}\text { Non-Hispanic Other } \\
\%(95 \% \mathrm{Cl})\end{array}$ \\
\hline & $(18.4-22.2)$ & $(20.9-26.9)$ & $(14.3-19.2)$ & & & & \\
\hline Tennessee & $\begin{array}{r}25.1 \\
(23.3-26.8)\end{array}$ & $\begin{array}{r}29.0 \\
(26.3-31.7) \\
\end{array}$ & $\begin{array}{r}21.4 \\
(19.2-23.5)\end{array}$ & $25.4(23.6-27.3)$ & $21.1(16.3-25.9)$ & $26.1(15.4-36.8)$ & $28.0(19.1-36.9)$ \\
\hline Texas & $\begin{array}{r}23.7 \\
(22.1-25.2)\end{array}$ & $\begin{array}{r}29.2 \\
(26.8-31.6)\end{array}$ & $\begin{array}{r}18.2 \\
(16.3-20.2)\end{array}$ & $25.8(23.7-27.9)$ & $22.4(17.2-27.6)$ & $20.8(18.0-23.6)$ & $25.8(18.7-32.9)$ \\
\hline Utah & $\begin{array}{r}19.1 \\
(18.0-20.2)\end{array}$ & $\begin{array}{r}22.5 \\
(20.8-24.2) \\
\end{array}$ & $\begin{array}{r}15.7 \\
(14.2-17.2)\end{array}$ & $17.8(16.6-19.0)$ & - & $24.3(20.4-28.3)$ & $27.2(20.6-33.9)$ \\
\hline Vermont & $\begin{array}{r}18.7 \\
(17.2-20.3)\end{array}$ & $\begin{array}{r}22.7 \\
(20.3-25.1)\end{array}$ & $\begin{array}{r}15.0 \\
(13.1-16.9)\end{array}$ & $18.2(16.6-19.8)$ & - & $28.9(14.3-43.5)$ & $28.3(18.8-37.9)$ \\
\hline Virginia & $\begin{array}{r}21.5 \\
(20.4-22.7)\end{array}$ & $\begin{array}{r}24.5 \\
(22.7-26.3)\end{array}$ & $\begin{array}{r}18.7 \\
(17.1-20.3)\end{array}$ & $22.6(21.2-24.1)$ & $19.4(16.6-22.1)$ & $17.7(13.6-21.7)$ & $21.8(16.7-26.9)$ \\
\hline Washington & $\begin{array}{r}22.5 \\
(21.5-23.5)\end{array}$ & $\begin{array}{r}26.5 \\
(25.0-28.0)\end{array}$ & $\begin{array}{r}18.6 \\
(17.3-19.9)\end{array}$ & $22.7(21.6-23.8)$ & $22.0(15.9-28.0)$ & $19.9(16.5-23.2)$ & $24.3(21.0-27.7)$ \\
\hline West Virginia & $\begin{array}{r}23.1 \\
(21.9-24.4)\end{array}$ & $\begin{array}{r}24.2 \\
(22.3-26.1)\end{array}$ & $\begin{array}{r}22.1 \\
(20.4-23.7)\end{array}$ & $23.1(21.8-24.4)$ & $27.4(19.3-35.5)$ & - & $26.3(18.8-33.8)$ \\
\hline Wisconsin & $\begin{array}{r}21.8 \\
(20.0-23.5)\end{array}$ & $\begin{array}{r}24.4 \\
(21.9-27.0)\end{array}$ & $\begin{array}{r}19.1 \\
(16.8-21.4)\end{array}$ & $21.7(19.9-23.5)$ & $19.2(11.6-26.8)$ & $20.3(10.4-30.3)$ & $25.0(17.0-33.0)$ \\
\hline Wyoming & $\begin{array}{r}24.3 \\
(22.1-26.4)\end{array}$ & $\begin{array}{r}27.7 \\
(24.4-30.9)\end{array}$ & $\begin{array}{r}20.7 \\
(17.9-23.5)\end{array}$ & $23.1(20.8-25.3)$ & - & $27.6(19.1-36.1)$ & $37.3(23.4-51.2)$ \\
\hline
\end{tabular}

Abbreviations: $\mathrm{Cl}$, confidence interval; - , estimates not presented because of relative standard error $>30 \%$.

a Persons aged $\geq 18$ years who reported having ever used an e-cigarette or other electronic "vaping" product, even just 1 time, during their lifetime. Excludes respondents whose ever using status was unknown.

The opinions expressed by authors contributing to this journal do not necessarily reflect the opinions of the U.S. Department of Health and Human Services, the Public Health Service, the Centers for Disease Control and Prevention, or the authors' affiliated institutions. 
Table 3. State-Specific Percentage of Cigarette Smoking Status Among Current E-cigarette Users ${ }^{a}$ Aged 18 Years or Older - Behavioral Risk Factor Surveillance System, United States, 2016

\begin{tabular}{|c|c|c|c|}
\hline State & $\begin{array}{l}\text { Percentage of Current Cigarette } \\
\text { Smokers }{ }^{b}, \%(95 \% \mathrm{Cl})\end{array}$ & $\begin{array}{l}\text { Percentage of Former Cigarette } \\
\text { Smokers }{ }^{c}, \%(95 \% \mathrm{Cl})\end{array}$ & $\begin{array}{l}\text { Percentage of Never-Cigarette } \\
\text { Smokers }, \%(95 \% \mathrm{Cl})\end{array}$ \\
\hline Alabama & $60.5(53.1-67.9)$ & $27.0(20.3-33.8)$ & $12.5(7.1-17.9)$ \\
\hline Alaska & $49.2(34.7-63.8)$ & $44.8(29.7-59.9)$ & - \\
\hline Arizona & $46.3(38.6-53.9)$ & $34.6(27.1-42.1)$ & $19.1(12.3-26.0)$ \\
\hline Arkansas & $55.4(43.9-67.0)$ & $26.4(16.9-35.9)$ & $18.1(8.0-28.2)$ \\
\hline California & $38.3(31.7-44.9)$ & $29.4(23.0-35.8)$ & $32.2(25.3-39.2)$ \\
\hline Colorado & $53.9(48.2-59.7)$ & $25.4(20.6-30.2)$ & $20.6(15.5-25.7)$ \\
\hline Connecticut & $52.2(43.7-60.7)$ & $26.0(19.1-32.9)$ & $21.8(13.9-29.7)$ \\
\hline Delaware & $54.1(42.6-65.6)$ & $24.8(15.2-34.3)$ & $21.1(10.7-31.6)$ \\
\hline District of Columbia & $46.5(31.6-61.3)$ & $23.2(10.4-36.0)$ & $30.3(15.6-45.0)$ \\
\hline Florida & $49.0(43.7-54.3)$ & $31.2(26.4-36.0)$ & $19.8(14.9-24.8)$ \\
\hline Georgia & $53.2(43.9-62.6)$ & $29.7(21.0-38.3)$ & $17.1(9.6-24.6)$ \\
\hline Hawaii & $44.1(36.1-52.0)$ & $31.0(23.7-38.3)$ & $25.0(17.4-32.5)$ \\
\hline Idaho & $51.0(40.0-62.0)$ & $34.4(24.1-44.7)$ & $14.6(6.6-22.5)$ \\
\hline Illinois & $55.5(45.7-65.3)$ & $29.3(20.0-38.6)$ & $15.2(8.5-21.9)$ \\
\hline Indiana & $58.5(51.5-65.6)$ & $28.7(22.4-35.0)$ & $12.7(7.5-18.0)$ \\
\hline lowa & $60.2(52.0-68.5)$ & $27.2(19.7-34.6)$ & $12.6(6.8-18.4)$ \\
\hline Kansas & $56.1(50.0-62.2)$ & $27.4(22.2-32.5)$ & $16.5(10.9-22.1)$ \\
\hline Kentucky & $51.6(44.7-58.5)$ & $32.9(26.4-39.4)$ & $15.5(9.0-22.0)$ \\
\hline Louisiana & $58.9(48.7-69.1)$ & $25.7(16.8-34.6)$ & $15.4(7.8-23.0)$ \\
\hline Maine & $64.6(56.3-73.0)$ & $28.2(20.2-36.3)$ & $7.1(3.2-11.0)$ \\
\hline Maryland & $49.8(42.3-57.3)$ & $33.2(26.1-40.3)$ & $17.0(11.0-22.9)$ \\
\hline Massachusetts & $51.3(42.7-59.9)$ & $27.5(19.5-35.6)$ & $21.2(13.5-28.8)$ \\
\hline Michigan & $57.2(51.2-63.2)$ & $21.6(17.2-26.0)$ & $21.2(15.3-27.0)$ \\
\hline Minnesota & $47.5(42.2-52.9)$ & $28.6(24.0-33.1)$ & $23.9(18.8-29.0)$ \\
\hline Mississippi & $56.3(46.1-66.5)$ & $21.4(13.4-29.5)$ & $22.3(12.9-31.6)$ \\
\hline Missouri & $72.1(64.3-79.9)$ & $19.3(12.5-26.2)$ & $8.6(4.0-13.1)$ \\
\hline Montana & $62.1(51.3-72.9)$ & $25.7(16.1-35.2)$ & - \\
\hline Nebraska & $59.5(52.4-66.6)$ & $21.5(16.0-26.9)$ & $19.0(12.4-25.7)$ \\
\hline Nevada & $51.3(41.6-61.0)$ & $28.6(20.1-37.0)$ & $20.1(11.9-28.3)$ \\
\hline New Hampshire & $66.7(57.4-75.9)$ & $21.3(13.4-29.1)$ & $12.1(5.8-18.3)$ \\
\hline
\end{tabular}

Abbreviations: $\mathrm{Cl}$, confidence interval; - , estimates not presented because of relative standard error $>30 \%$.

${ }^{a}$ Persons aged $\geq 18$ years who reported currently using e-cigarette every day or some days. Respondents with unknown current cigarette smoking status ( $0.5 \%$ of current e-cigarette users) were excluded.

${ }^{b}$ Persons aged $\geq 18$ years who reported currently using e-cigarette every day or some days and also reported having smoked $\geq 100$ cigarettes during their lifetime and smoked every day or some days at the time of survey.

${ }^{c}$ Persons aged $\geq 18$ years who reported currently using e-cigarette every day or some days and reported having smoked $\geq 100$ cigarettes during their lifetime but did not smoke every day or some days at the time of survey.

${ }^{d}$ Persons aged $\geq 18$ years who reported currently using e-cigarette every day or some days and reported never having smoked or having smoked $<100$ cigarettes during their lifetime at the time of survey. 
(continued)

Table 3. State-Specific Percentage of Cigarette Smoking Status Among Current E-cigarette Users ${ }^{a}$ Aged 18 Years or Older - Behavioral Risk Factor Surveillance System, United States, 2016

\begin{tabular}{|c|c|c|c|}
\hline State & $\begin{array}{l}\text { Percentage of }{ }_{b} \text { Current Cigarette } \\
\text { Smokers }{ }^{b}, \%(95 \% \mathrm{Cl})\end{array}$ & $\begin{array}{l}\text { Percentage of Former Cigarette } \\
\text { Smokers }{ }^{c}, \%(95 \% \mathrm{Cl})\end{array}$ & $\begin{array}{l}\text { Percentage of Never-Cigarette } \\
\text { Smokers }{ }^{\mathrm{a}}, \%(95 \% \mathrm{Cl})\end{array}$ \\
\hline New Jersey & $54.9(44.1-65.6)$ & $24.8(16.0-33.7)$ & $20.3(11.0-29.6)$ \\
\hline New Mexico & $50.9(39.9-62.0)$ & $25.6(15.8-35.3)$ & $23.5(14.7-32.3)$ \\
\hline New York & $48.5(42.6-54.4)$ & $27.4(22.2-32.7)$ & $24.1(18.6-29.6)$ \\
\hline North Carolina & $52.4(44.5-60.4)$ & $33.2(25.5-40.8)$ & $14.4(8.9-19.8)$ \\
\hline North Dakota & $64.9(54.2-75.6)$ & $25.7(16.3-35.1)$ & - \\
\hline Ohio & $65.6(59.4-71.8)$ & $21.1(16.0-26.2)$ & $13.3(8.8-17.9)$ \\
\hline Oklahoma & $54.5(46.8-62.2)$ & $31.7(24.9-38.4)$ & $13.9(7.5-20.2)$ \\
\hline Oregon & $65.0(56.9-73.0)$ & $24.6(17.6-31.6)$ & $10.5(5.2-15.7)$ \\
\hline Pennsylvania & $58.4(50.7-66.0)$ & $27.0(19.9-34.1)$ & $14.6(9.1-20.1)$ \\
\hline Rhode Island & $50.6(39.4-61.9)$ & $31.0(21.2-40.7)$ & $18.4(8.4-28.3)$ \\
\hline South Carolina & $58.9(52.0-65.7)$ & $27.9(21.8-34.1)$ & $13.2(8.2-18.3)$ \\
\hline South Dakota & $70.5(58.2-82.9)$ & $20.0(8.5-31.5)$ & - \\
\hline Tennessee & $63.0(54.8-71.3)$ & $22.9(16.0-29.8)$ & $14.0(7.4-20.7)$ \\
\hline Texas & $51.3(42.5-60.0)$ & $37.3(28.5-46.0)$ & $11.4(6.2-16.7)$ \\
\hline Utah & $36.7(30.5-42.9)$ & $35.1(28.9-41.3)$ & $28.2(22.0-34.4)$ \\
\hline Vermont & $53.0(41.1-64.8)$ & $19.8(12.4-27.2)$ & $27.2(14.9-39.6)$ \\
\hline Virginia & $45.0(38.3-51.7)$ & $30.6(24.2-36.9)$ & $24.4(18.2-30.7)$ \\
\hline Washington & $45.2(39.8-50.6)$ & $33.1(28.1-38.0)$ & $21.7(16.8-26.5)$ \\
\hline West Virginia & $63.5(56.4-70.7)$ & $29.9(23.2-36.7)$ & - \\
\hline Wisconsin & $56.6(46.7-66.5)$ & $23.9(16.2-31.7)$ & $19.5(10.3-28.6)$ \\
\hline Wyoming & $59.4(48.1-70.7)$ & $23.1(13.9-32.3)$ & $17.5(8.2-26.8)$ \\
\hline
\end{tabular}

Abbreviations: $\mathrm{Cl}$, confidence interval; - , estimates not presented because of relative standard error $>30 \%$.

${ }^{a}$ Persons aged $\geq 18$ years who reported currently using e-cigarette every day or some days. Respondents with unknown current cigarette smoking status (0.5\% of current e-cigarette users) were excluded.

${ }^{\mathrm{b}}$ Persons aged $\geq 18$ years who reported currently using e-cigarette every day or some days and also reported having smoked $\geq 100$ cigarettes during their lifetime and smoked every day or some days at the time of survey.

${ }^{c}$ Persons aged $\geq 18$ years who reported currently using e-cigarette every day or some days and reported having smoked $\geq 100$ cigarettes during their lifetime but did not smoke every day or some days at the time of survey.

${ }^{d}$ Persons aged $\geq 18$ years who reported currently using e-cigarette every day or some days and reported never having smoked or having smoked $<100$ cigarettes during their lifetime at the time of survey. 